
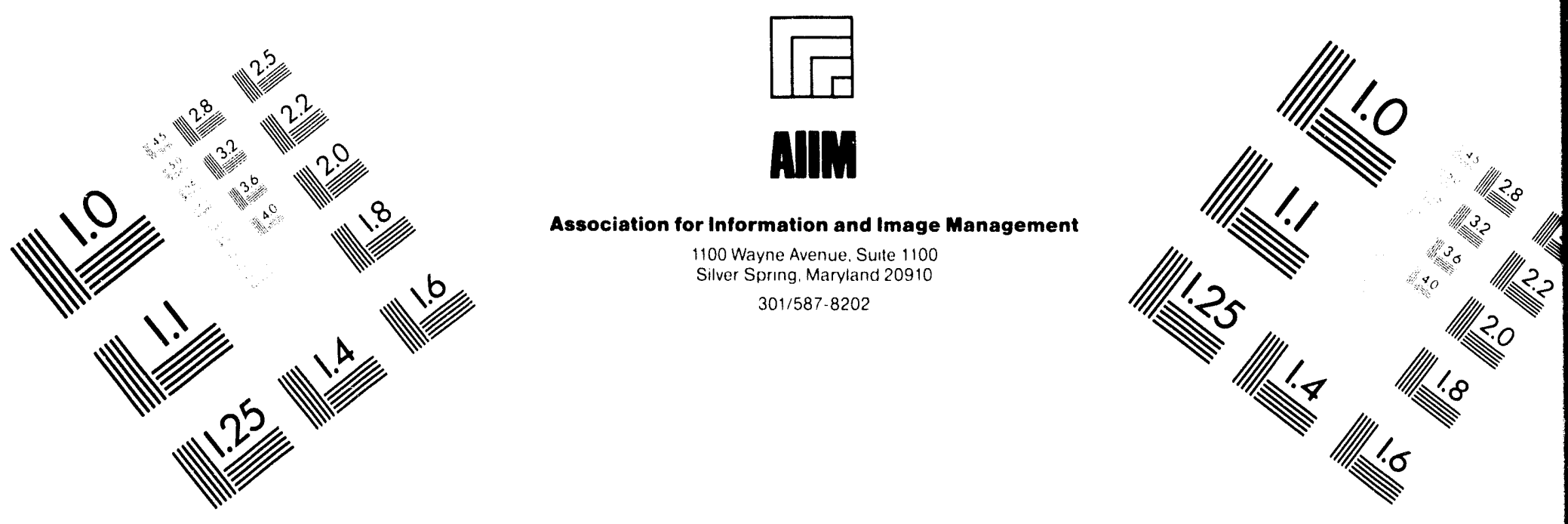

\title{
Centimeter
}

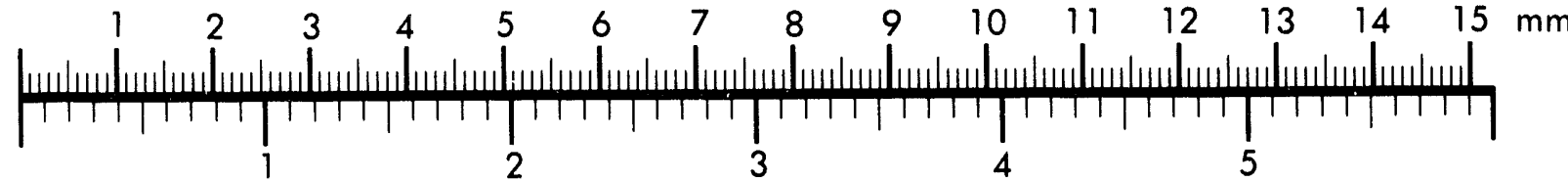

Inches
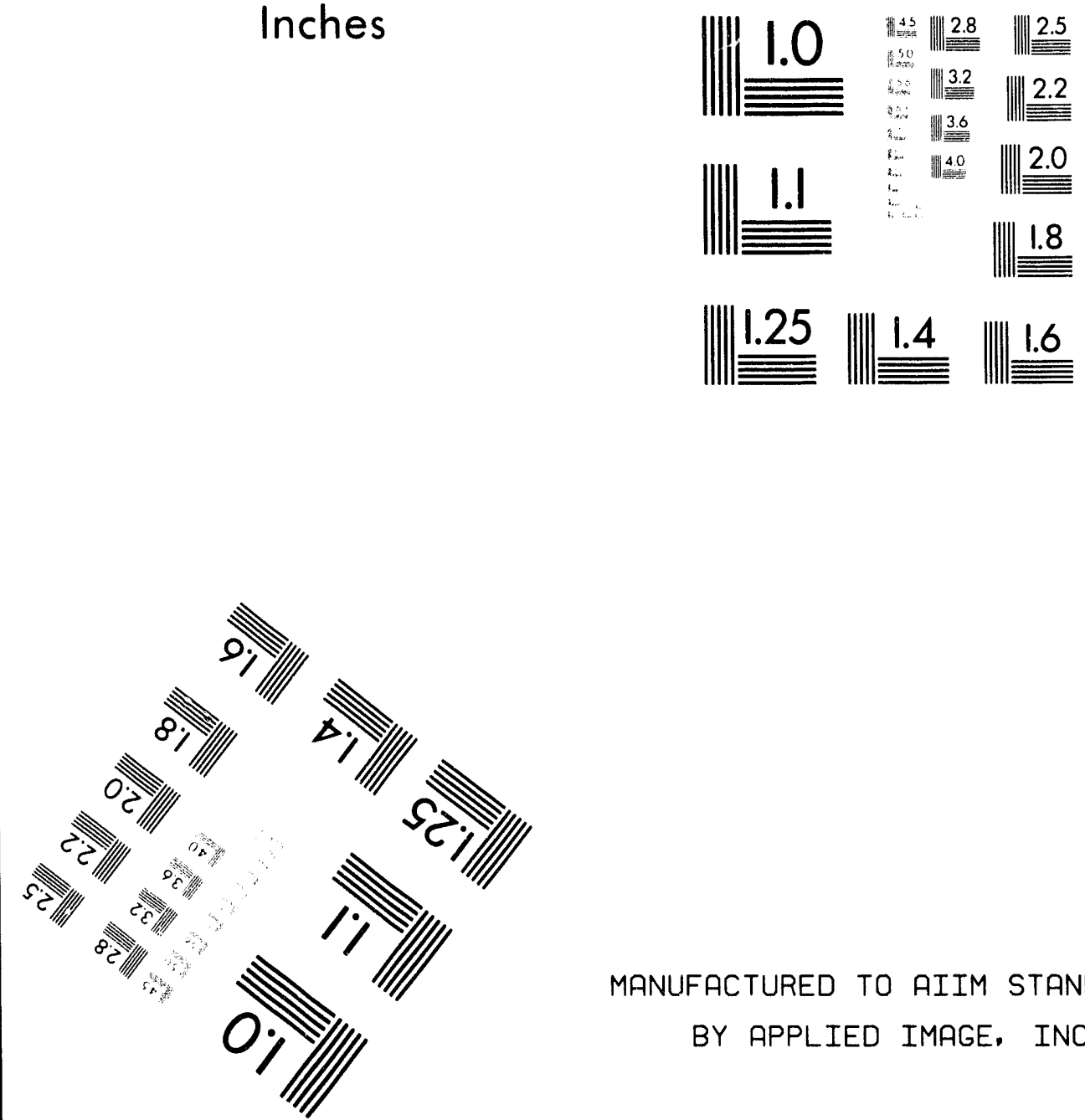

MANUFACTURED TO AIIM STANDARDS

BY APPLIED IMAGE. INC.

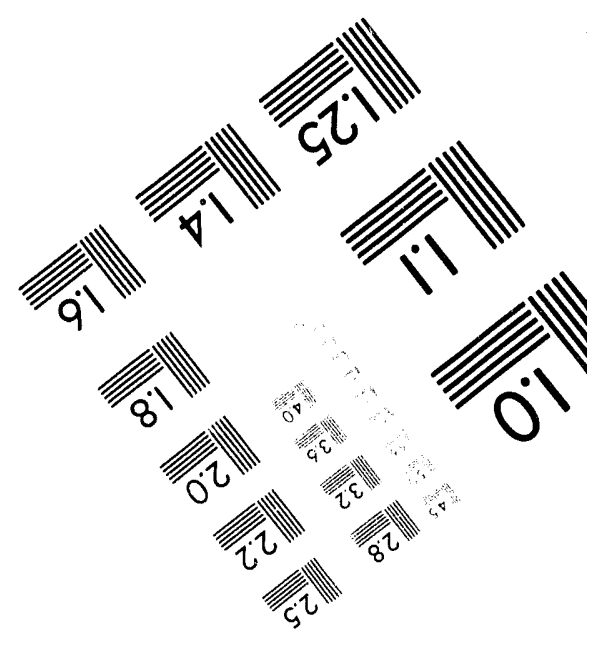



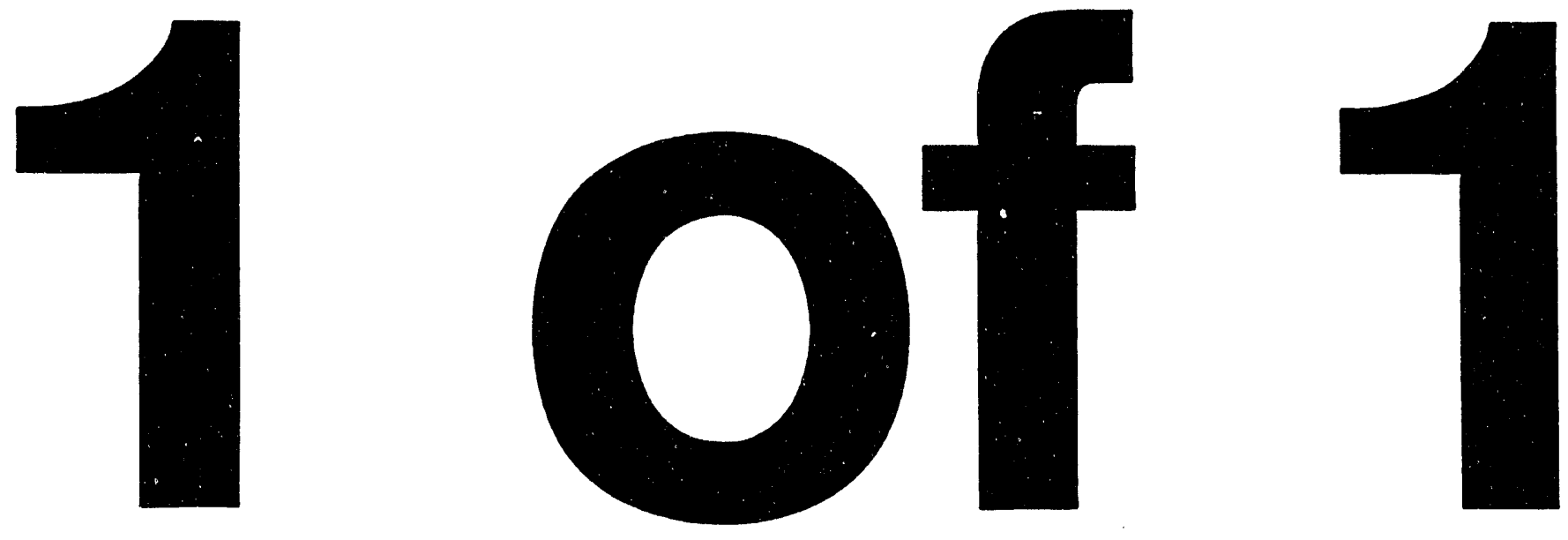


\section{NOT MEASUREMENT}

SENSITIVE

DOE-STD-1022-94

March 1994

\section{DOE STANDARD}

\section{NATURAL PHENOMENA HAZARDS SITE CHARACTERIZATION CRITERIA}

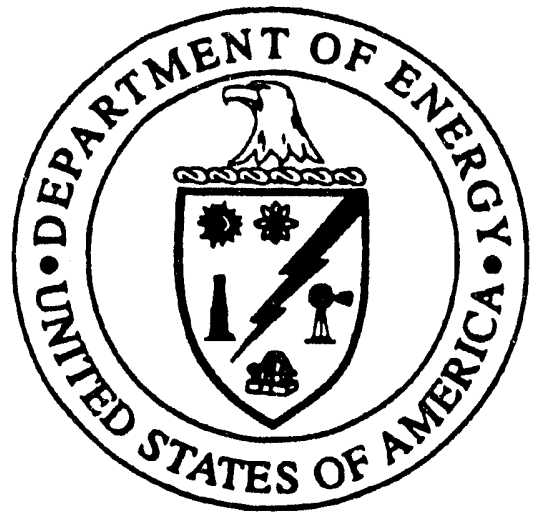

U.S. Department of Energy Washington, D.C. 20585 


\section{FOREWORD}

The Department of Energy (DOE) has issued an Order (DOE-5480.28) which establishes policy and requirements for Natural Phenomena (NPH) mitigation for DOE sites and facilities. To implement the NPH mitigation requirements, several standards have been developed for compliance with DOE Order 5480.28. This standard provides general and detailed requirements for site characterization which provides the necessary site-specific information to implement DOE-STD-1023-94 (draft), "Natural Phenomena Hazards Assessment Criteria." The DOE-STD-1023-94 (draft) establishes adequate design basis load levels and in turn provides necessary information to implement DOE-STD-1020-94 for NPH design and evaluation criteria for DOE facilities.

The requirements given in this standard should be used in conjunction with other DOE Orders and Standards as listed in Section 2 (Applicable Documents) of this Standard and with other pertinent National consensus codes and standards such as UBC (Uniform Building Code), ASCE-4 (Seismic Analysis of Safety-related Nuclear Structures), NBC (National Building Code), FEMA 222 (NEHRP Recommended Provisions for the Development of Seismic Regulations for New Buildings), etc. In addition, this standard should also be used in conjunction with Nuclear Regulatory Commission (NRC) Regulatory Guides (e.g., R. G. 4.7; DG 1015; DG 4003) and Standard Review Plan (e.g., SRP 2.5.2).

This DOE Standard is approved for use by all departments and contractors of the Department of Energy.

The preparation of this document utilizes a Preparing Activity to prepare the document and a Review Activity to provide formal review and comment. The Preparing Activity was conducted by the Fission Energy and Systems Safety Program (FESSP) of Lawrence Livermore National Laboratory (LLNL) under the direction of the DOE NPH subcommittee and NPH Standard Managers from the offices of $\mathrm{EH}-64, \mathrm{EH}-33$ and DP.621.

The Review Activity consists of an initial review by DOE Standards Coordinators and a final review by the review group suggested by the Standard Managers. The standard was circulated to DOE Standards Coordinators of all DOE Headquarters and Field Offices for review and comment. The comments received were resolved and incorporated in the standard. 


\section{TABLE OF CONTENTS}

1. INTRODUCTION 1

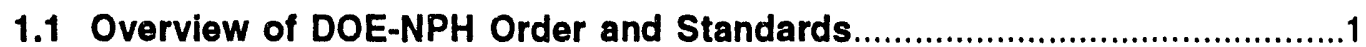

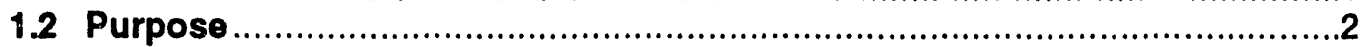

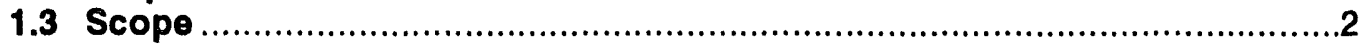

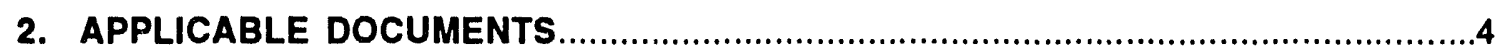

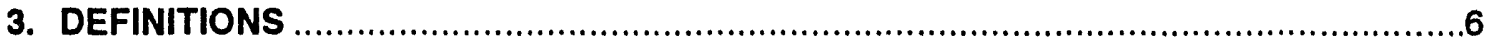

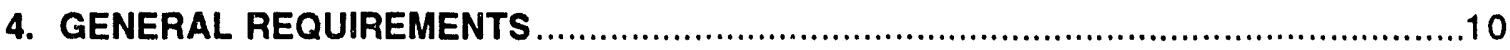

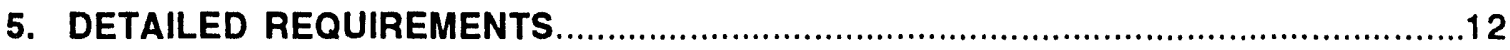

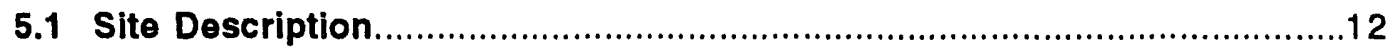

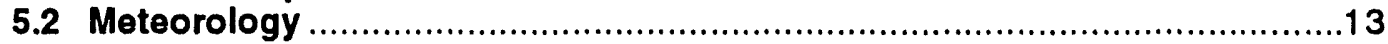

5.2.1 Regional Climatology Description and History ...............................13

5.2.2 Wind Data Collection ......................................................................14

5.2.2.1 Straight Winds......................................................... 14

5.2.2.2 Hurricane Winds .........................................................14

5.2.2.3 Tornado Winds...................................................15

5.2.3 Precipitation and Snowfall Data ...................................................16

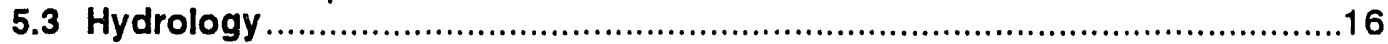

5.3.1 Hydrological Data Collection..................................................17

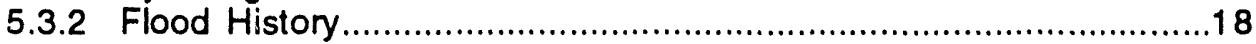

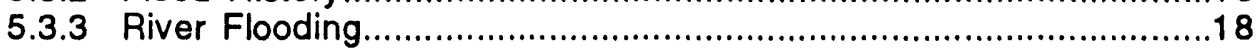

5.3.4 Dam, Levee, or Dike Failure...................................................19

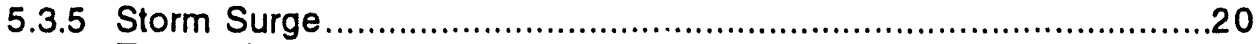

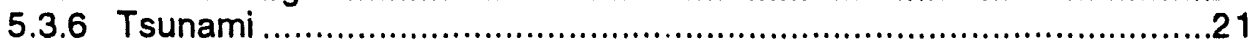

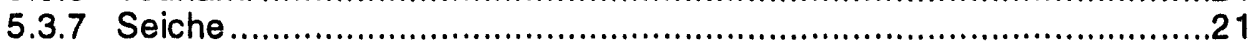

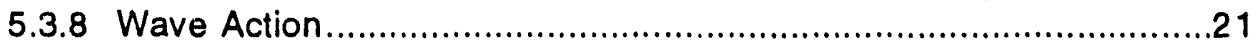

5.3.9 Landslide and Volcano Created Natural Hydrological Consequences 21

5.3.10 Flood Runoff/Drainage................................................................22

5.3.11 Ground Water Hydrology .....................................................22

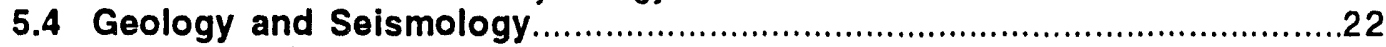

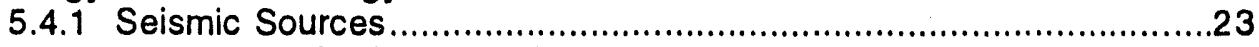

5.4.1.1 Seismic source identification data ..................................23

5.4.1.2 Seismic source characterization ...............................27

5.4.1.3 Surface-fault rupture and associated deformation.............28

5.4.2 Vibratory Ground Motions ........................................................29

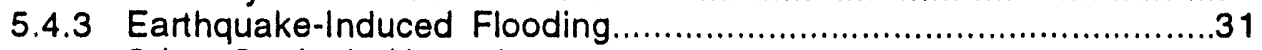

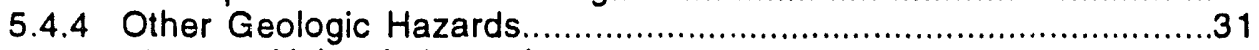

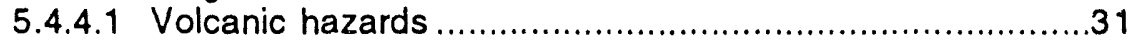

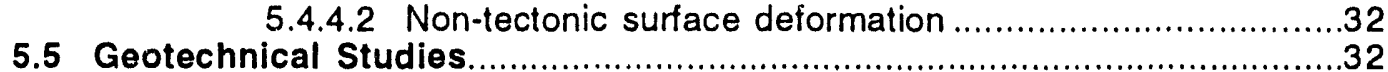

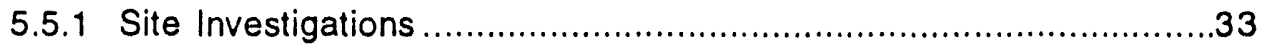

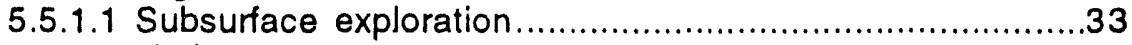

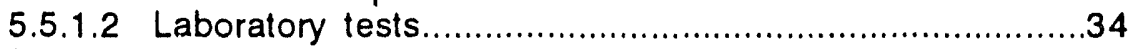

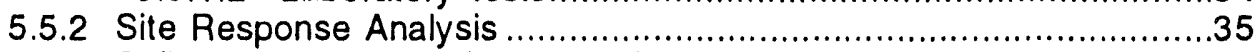

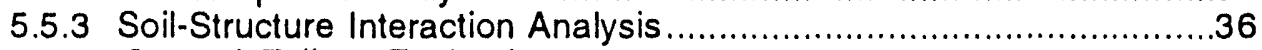

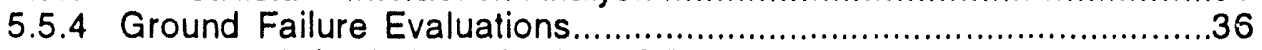

5.5.4.1 Seismic Liquefaction of Soils .......................................36

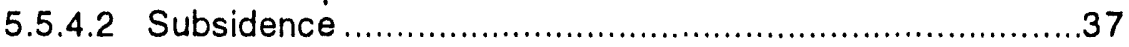

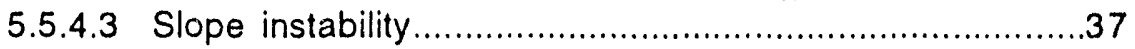

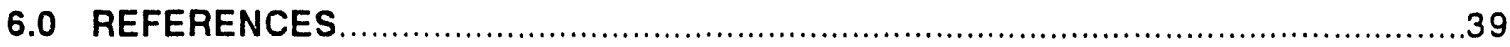




\section{INTRODUCTION}

\subsection{OVERVIEW OF DOE-NPH ORDER AND STANDARDS}

a. The Department of Energy (DOE) has established policy and requirements for natural phenomena hazard (NPH) mitigation for DOE sites and facilities using a graded approach as specified by DOE Order 5480.28, "Natural Phenomena Hazards Mitigation". To implement the NPH mitigation requirements, five standards have been or are being developed for compliance with DOE Order 5480.28. Five DOE Standards provide specific acceptance criteria for various aspects of NPH to meet the requirement of DOE Order 5480.28. These requirements should be used in conjunction with other pertinent documents such as DOE Orders (DOE 6430.1A, 5480.23, 5480.30, 5481.13 etc.,), consensus national standards, model building codes, and industry accepted codes and specifications. Figure 1 shows a conceptual NPH design framework which identifies how the DOE NPH standards are used to assess NPH design requirements.

b. The studies of site characteristics should be performed and existing data for site characteristics related to NPH should be evaluated in accordance with this standard, DOE-STD-1022-94. The site characterization provides the necessary site-specific information to implement DOE-STD-1023-94, "Natural Phenomena Hazards Assessment Criteria" which provides criteria for hazard assessment to ensure that adequate design basis load levels are established. The DOE-STD-1023-94 in turn provides necessary information to implement DOE-STD-1020-94 for NPH design and evaluation criteria for DOE facilities.

c. DOE Order 5480.28 also established performance categories and target probabilistic pertormance goals for each category. Performance categories and performance goals range from those for conventional buildings to those facilities with hazardous materials or operations. NPH performance categories are specified in DOE-STD-1021-93 using overall facility hazard classification. The guidance for the preparations of facility hazard classification and accident analyses techniques is established in DOE-STD-1027-92.

d. The NPH requirements have been developed to provide the necessary information that assess the NPH safety basis for DOE facilities, which is documented in Safety Analysis Reports (SAR). The overall approach for NPH mitigation is consistent with the graded approach embodied in the SAR. The selection of structure, systems and components (SSCs) which require NPH design is based on the potential hazard from the facility quantified as necessary through accident analysis. Once the SSC's have been assessed, DOE Order 5480.28 specifies the NPH requirements to ensure that the SSC's are adequately designed to resist $\mathrm{NPH}$. 


\section{DOE ORDER 5480.23 \& 5481.1B PROCESS}

DOE-STD-1027

DOE $6430.1 \mathrm{~A}$ $\& 5480.30$

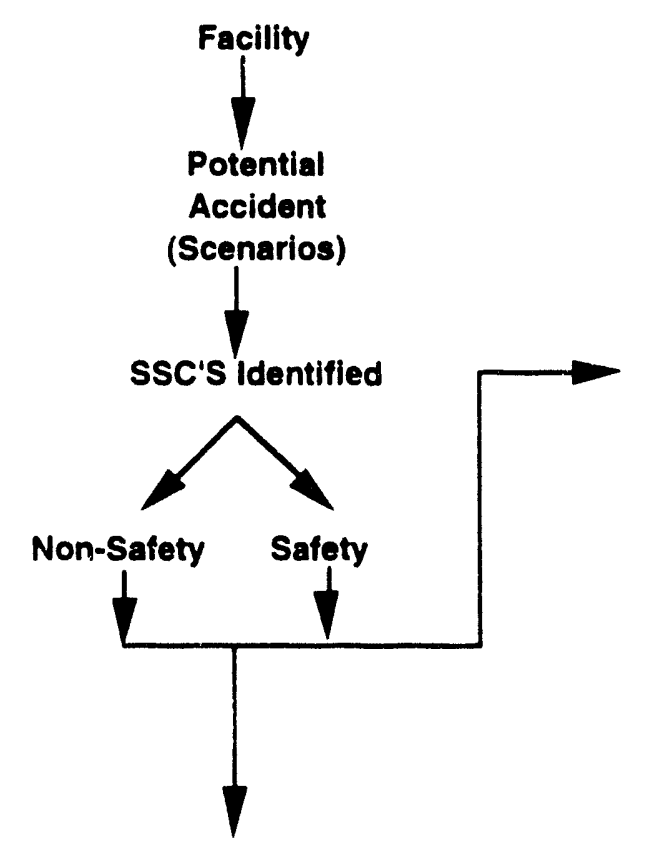

DOE ORDER 5480.28 PROCESS

NPH Hazard Characterization

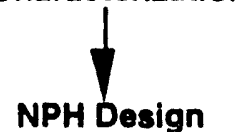
Input<smiles>C[13CH]</smiles>

NPH Categorization of SSC'S

DOE-STD-1021<smiles>CCCCCCCC</smiles>

NPH Design Criteria

DOE-STD-1020

DOE-STD-1022

DOE-STD-1023

\&

DOE-STD-1024

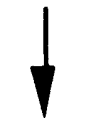

\section{FACILITY NPH SAFETY DOCUMENTED AS PART OF SAR}

Figure 1. Natural Phenomena Design Input Conceptual Framework

\subsection{PURPOSE}

a. The purpose of this standard, DOE-STD-1022-94, is to provide criteria for site characterization to provide site-specific information needed for implementing DOE 5480.28 requirements. Additionally, the purpose of this standard is also to develop a sitewide database related to NPH that should be obtained to support individual safety analysis reports (SARs). Appropriate approaches are outlined to ensure that the current state-of-the-art methodology is being used in the site characterization.

\subsection{SCOPE}

a. The criteria and recommendations in this standard shall apply to site characterization for the purpose of mitigating Natural Phenomena Hazards in all DOE facilities covered by DOE Order 5480.28 . Criteria for site characterization not related to NPH are generally not included in this document unless they are deemed necessary for clarification. General and detailed site characterization requirements are provided in the areas of meteorology, hydrology, geology, seismology and geotechnical studies. 


\section{APPLICABLE DOCUMENTS}

a DOE Order 6430.1A, "General Design Criteria", of 4-6-89, which contains the criteria for design and construction of DOE facilities.

b. DOE Order 5480.1B, "Environment, Safety and Health Program for DOE Operations", of 9-23-86, which establishes the Environment, Safety, and Health (ES \&H) Program for DOE Operations.

c. DOE Order 5480.23, "Nuclear Safety Analysis Reports", of 4/10/92, which specifies requirements for safety analysis involving DOE nuclear facilities and for submittal, review, and approval of contractor plans and programs

1. DOE Order 5480.28, "Natural Phenomena Hazards Mitigation," of 1-15-93, which establishes policy and requirements for natural phenomena hazard (NPH) mitigation for DOE sites and facilities using a graded approach.

e. DOE Order 5480.30, "Nuclear Reactor Safety", of 1-19-93, which specifies requirements for DOE nuclear reactor safety.

f. DOE Order 5481.1B, "Safety Analysis and Review System", of 9-23-86, which establishes uniform requirements for the preparation and review of safety analyses of DOE operations.

g. DOE Order 5700.6c, "Quality Assurance", of 8-21-91, which establishes quality assurance requirements.

h. DOE-STD-1020-94, "Natural Phenomena Hazards Design and Evaluation Criteria for Department of Energy Facilities", March, 1994.

i. DOE-STD-1021-93, "Natural Phenomena Hazards Performance Categorization Criteria for Structures, Systems, and Components", July 1993.

j. DOE-STD-1023-94, "Natural Phenomena Hazards Assessment Criteria", Draft, 1994.

k. DOE-STD-1024-92, "Guidelines for Use of Probabilistic Seismic Hazard Curves at DOE Sites", December, 1992. 
DOE-STD-1022-94

I. DOE-STD-1027-92, "Hazard Categorization and Accident Analysis Techniques for Compliance with DOE Order 5480.23, Nuclear Safety Analysis Reports" December, 1992.

m. DOE-STD-3009-93," Preparation Guide for U.S. DOE Non-reactor Nuclear Facility Safety Analysis Reports", Draft March, 1994. 


\section{DOE-STD-1022-94}

\section{DEFINITIONS}

Annual Flood The maximum instantaneous peak discharge in each year of record.

BasinWatershed The total area from which surface runoff is carried away by a drainage system.

Facillity One or more building(s) or structure(s), including systems and components, dedicated to common function (includes operating and non-operating facilities and facilities slated for decontamination and decommissioning).

Graded Approach An approach where the design, evaluation, and construction process for SSCs require emphasis commensurate with their mission, cost and potential consequences of failure. Accordingly, performance categories with specified performance goals ranging from low to extremely low probability of NPH failure are specified in DOE-STD-1020-94.

Hurricane intensity Hurricane-type storms are events associated with maximum sustained 1- minute wind speeds in excess of $75 \mathrm{mph}$. The U.S. National Weather Service uses the Saffir/Simpson scale to rate the intensity and the damage potential of hurricanes. This scale is divided into 5 numbers, 1 through 5. Larger scale numbers represent high wind speeds at which considerable damage occurs.

Liquefaction The sudden loss of shear strength and rigidity of saturated, cohesionless soils, due to steady state ground water flow or vibratory ground motion. The term seismic liquefaction (or cyclic mobility) is used in this Standard for liquefaction phenomena associated with seismic motions.

Magnitude A measure of the size of an earthquake. It is related to the energy released in the form of seismic waves. Magnitude means the numerical value on a standardized scale such as, but not limited to, Moment Magnitude, Surface Wave Magnitude, Body Wave Magnitude, or Richter Magnitude scale.

Model Building Codes Building codes containing design and construction requirements that apply to normal commercial buildings (e.g., 1991 Uniform Building Code [UBC] of the International Conference of Building Officials [ICBO]; National Buildign Code [NBC] of the Building Officials and Code Administrators International [BOCA]).

Natural Phenomena Hazard (NPH) An act of nature (for example, earthquake, wind, hurricane, tornado, flood, precipitation, volcanic eruption, lightning strike, or extreme cold or heat) which poses a threat or danger to workers, the public, or to the environment by potential damage to structures, systems, and components. 
One- (Five-) Hundred-Year Flood A flood level which will be equaled or exceeded with a $1.0(0.2)$ percent chance in any given year.

Performance Category (PC) A classification using a graded approach in which structures, systems, or components in a category are designed to assure similar levels of protection (i.e., meet the same performance goal) during natural phenomena hazard events. Five performance categories ranging from 0 to 4 in order of increasing level of protection have been defined in DOE-STD-1021-93, (e.g., PC-1 for building structures with potential human occupancy; PC-4 for high hazard facilities such as nuclear power plants).

Performance Goal The mean annual probability of exceedance of acceptable behavior limits used as a target to develop natural phenomena hazard mitigation requirements. Numerical values for performance goals for each performance category are provided in Table 1 of DOE Order 5480.28 .

Probable Maximum Flood The flood that may be expected from the most severe combination of critical meteorological and hydrologic conditions that are reasonably possible in the drainage basin under study.

Probable Maximum Precipitation The greatest amount of precipitation for a given duration meteorologically possible for a given size storm area at a particular location at a particular time of year, with no allowance made for long-term climatic trends.

Probabilistic Method A technique which uses distributions of parameters (including uncertainty and randomness) to perform an analysis. Results are expressed in terms of probabilistic distributions which quantity uncertainty.

Response Spectrum A curve calculated from an earthquake accelerogram that gives the value of peak response in terms of acceleration, velocity, or displacement of a damped linear oscillator (with a given damping ratio) as a function of its period (or frequency) of vibration. For design purposes, a set of response spectra are usually generated for different damping ratios.

River Mile Number of miles to the mouth of a river along the course of the river. 
Seismic Sources Portions of the earth that have a potential for abrupt releases of energy in the earth's lithosphere, or to cause earthquakes. Seismic sources may include a region of diffuse seismicity (seismotectonic province) and/or a well-defined tectonic structure which can generate both earthquakes and ground deformation.

Seismogenic crust is a portion of the earth's crust capable of generating earthquakes.

Site The area comprising or within a DOE jurisdictional unit with one or more DOE facilities that can be represented by the same natural phenomena hazards.

Stage Elevation above some arbitrary zero datum of the water surface at a gauging station.

\section{Structures, Systems, and Components (SSCs)}

(1) Structure is an element, or a collection of elements to provide support or enclosure such as a building, free standing tank, basins, dikes, or stacks.

(2) System is a collection of components assembled to perform a function such as piping, cable irays, conduits, or HVAC (Heating, Ventilation and Air Conditioning).

(3) Component is an item of equipment such as a pump, valve, or relay, or an element of a larger array such as a length of pipe, elbow, or reducer.

Subsidence The settlement or sinking of surficial geological materials on a regional or local scale.

Surface Deformation Distortion of soils or rocks at or near the ground surface by the processes of folding and faulting as a result of various earth forces. Tectonic surface deformation is associated with earthquake processes.

Surface Faulting Differential ground displacement at or near the surface caused directly by fault movement and is distinct from non tectonic types of ground disruptions, such as landslides, fissures, and craters.

Tornado Intensity Tornado intensity is generally represented by the Fujita scale. This scale, now routinely used by the National Weather Service is generally referred to as the F-scale. The F-scale is a simple method for determining the wind speed of each tornado based on the damage observed. The scale is divided into 13 numbers although no F-6 or greater tornadoes have been observed. 
Wind Speed A scalar quantity used with respect to averaging time, ground terrain, and height above ground. Wind speed can be described in terms of peak wind, mean wind, or fastest mile wind. Unless mentioned otherwise, fastest-mile wind speed quantity measure is used in model building codes and national consensus standards. Each of these terms has a unique meaning:

Peak wind speed is the maximum instantaneous value of the wind speed recorded. Peak wind speed generally occurs in a 1 to 3 second gust.

Mean wind speed is the value of the wind speed averaged over some time period, usually 1 or 10 minutes.

Fastest-mile wind speed is defined as the highest sustained average wind speed based on the time required for a mile long sample of air to pass a fixed point. 


\section{GENERAL REQUIREMENTS}

a. The meteorologic, hydrologic, geologic, seismological and geotechnical characteristics of a site and its environs shall be investigated in sufficient scope and detail to provide reasonable assurance that they are sufficiently well understood to permit an adequate evaluation of the proposed or existing site, and to provide sufficient information to support the evaluations required by other DOE standards (e.g. DOE-STD-1023 and DOE-STD-1020, etc.,) for implementation of NPH mitigation requirements specified in DOE 5480.28. Site information is necessary for identifying and evaluating potential external accident initiators and for identifying and analyzing accident consequences external to the facility (DOE-STD-3009-93). The size of the region to be investigated and the type of data pertinent to the investigations shall be determined by the nature of the region surrounding the proposed or existing site, and shall be consistent with the performance category of the facilities. The site characterization information should be reviewed at the same time the hazard curves are being reviewed per DOE-STD-1023-94 which is about every 10 years.

b. For sites containing facilities with SSCs in oniy Performance Category 1 or 2, at a minimum, sufficient site information shall be collected so that the NPH assessment (DOE-STD-1023-94) and the design and evaluation of the facilities (DOE-STD-1020-94) can be conducted by following the procedures provided in model building codes or national consensus standards (e.g., hazard zone maps, site coefficients, etc.,).

c. For sites containing facilities with SSCs in Performance Category 3 or 4 , more extensive site characterization shall be carried out to obtain the site information for the site-specific natural phenomena hazard assessment, and design and evaluation of DOE facilities in accordance with DOESTD-1023-94 and DOE-STD-1020-94, respectively.

d. The site characterization shall be carried out by a review of the pertinent literature and field investigations and shall follow the detailed requirements given in Section 5 for various NPHs. Site experts (in various NPH) with the knowledge and experience of fulfilling the requirements stated in the federal regulations and standards for DOE site characterization should be consulted for defining the program of investigations. Data and other information obtained from prior investigations shall be used, supplemented by additional investigations at the specific location as deemed necessary by the design professional and geoscientists. 
e. A quality assurance (QA) program and peer review group for data used in site characterization are required. The quality assurance program should be developed in accordance with the DOE Quality Assurance Plan (DOE Order 5700.6c). The peer review is to be performed by independent qualified personnel with extensive knowledge and experience in various aspects of NPH site characterization. The quality assurance program and peer review should be conducted within the framework of a graded approach with increasing level of rigor employed from Performance Category 1 to 4 . For sites containing facilities with SSCs in Performance Category 1 or 2, a program conforming to model building codes requirements will be sufficient. For sites containing facilities with SSCs in Performance Category 3 or 4, a program approaching that or similar to that required for a nuclear power plant is necessary. The peer review group in theses categories would help establish the site characterization program at the outset, help resolve site-specific problems as they arise, and help DOE to approve the results. The review group would be involved from the beginning and by the time the assessment is complete, would have first-hand familiarity with problems/solutions developed during the effort.

f. DOE Order 5480.28 indicates that the requirements provided in that Order shall be used in conjunction with the General Design Criteria in DOE Order 6430.1A and other Departmental Design Criteria as applicable. DOE 6430.1A contains siting information which is pertinent to the provisions of this standard.

g. 10 CFR Part 100 Appendices $A$ and $B$ describe the nature of specific investigations to determine site suitability concerning seismic and geologic factors for commercial nuclear power plants. U.S. NRC Regulatory Guide DG-1015 (USNRC, 1992a), U.S. NRC Regulatory Guide DG-4003 (USNRC, 1992b), and revised Standard Review Plan 2.5.2 (USNRC, 1992c) provide general guidelines for identification and characterization of seismic sources and defining ground motion for commercial nuclear power stations. These criteria may be used for the site characterization for facilities containing SSCs in Performance Category 3 or 4 .

h. DOE sites are encouraged to develop a sidewide NPH database that can be referenced by facility specific SARs. Such an approach would minimize the amount of written material that would be required in individual SARs. 


\section{DETAILED REQUIREMENTS}

a. Criteria are presented in this paragraph for meteorological, hydrological, geological, seismological, and geotechnical studies to characterize the site and to provide the necessary site-specific information. The required information is necessary to complete the hazard assessments described in DOE-STD1023-94 and in tum to provide input for design and evaluation requirements described in DOE-STD1020-94. The scope and degree of detail of investigations to address these natural phenomena hazards depend on several factors, which include: the performance categories of the SSCs making up the facilities; the hazard classification of the facilities; the subsurface conditions at the site; the meteorologic, hydrologic, and seismotectonic environment of the site region; and the extent of prior knowledge, investigations, and data regarding the site and site region. Although more detailed investigations are generally appropriate for facilities having higher performance categories, it should be kept in mind that investigations of lesser scope and detail may be appropriate when the existing knowledge of the site and region is extensive and up-to-date. Similarly, although less detailed investigations would generally be commensurate with lower performance categories, more comprehensive investigations may be needed if a critical site hazard exists and/or if investigations to define the hazards have not previously been conducted. The detailed requirements in this section are applicable for obtaining the site information which is needed for implementation of DOE NPH requirements.

b. The criteria needed to provide site-specific information to perform wind, flood, seismic, and other geological hazard analyses are provided in Sections 5.1 to 5.5 (see also DOE-STD-3009-93). The meteorological-related hazards include wind hazards due to storms and tornadoes, and flood hazards due to intense precipitation and snow. Characterization of the information needed to assess these hazards is addressed in Section 5.2. The hydrologic hazards include flooding either from surface water or ground water. Section 5.3 provides criteria to collect site-specific information needed to quantify these hazards. Criteria for seismic hazard characterization, volcanic hazards, and non-tectonic surface deformation are provided in Section 5.4. Section 5.5 provides specific requirements to conduct geotechnical studies relevant to the hazards being studied. 


\subsection{SITE DESCRIPTION}

a. The description of the site and boundaries shall, at a minimum, include the following:

1. The geographical location of the site for which there shall be no ambiguity for estimating the distance from the site to the sources of potential hazards, and for the use of hazard zone maps, such as those provided in the model building codes.

2. A general location map to clearly define the boundary of the site and to show the relative distance from the site to natural and man-made features, and to sources of potential hazards, such as rivers, lakes, oceans, volcanoes, faults, dams, levees, etc.

3. Detailed mapping of topographic, hydrologic, surface, and subsurface geologic features, as appropriate for the particular site conditions, with scales and contours suitable for NPH assessment. The topographic map shall also show the character of surface drainage patterns and the topographic elevation of the site relative to near-by hydrologic features, such as rivers, streams, or lakes and local surface drainage channels, ponds, springs and sinks at the site.

\subsection{METEOROLOGY}

a. The sources of meteorological hazards include winds (straight, hurricane, and tornado winds), precipitations and temperature changes. Meteorological data to be collected includes : (1) wind speeds and direction, (2) precipitation and rainfall records, and (3) air temperature. The extent of meteorological data needed to be collected is dependent upon the performance categories of facility SSCs.

b. For sites containing facilities with SSCs in Performance Category 1 or 2 , it is sufficient to utilize results of previous probabilistic wind hazard studies, if available, or to utilize information provided in model building codes or national consensus standard such as ANSI/ASCE 7-88 (ASCE, 1988). For sites containing facilities with SSCs in Performance Category 3 or 4 , and for which no up-to-date site-specific probabilistic wind hazard studies have been performed in accordance with specifications in DOE-STD. 1023-94, site-specific characterization criteria are provided in the following paragraphs. 


\subsubsection{Regional Climatology Description and History}

a. The general climate of the region shall be described with respect to the types of topographic influences, general airflow patterns, temperature and humidity, precipitation, and relationships between regional atmospheric conditions and local meteorological conditions.

b. Regional extreme climatology history shall be reported with dates, event descriptions, and related information on their effects.

\subsubsection{Wind Data Collection}

a. A distinction is made between three types of wind; straight winds, hurricane, and tornado winds. Site specific characterization needs to be performed for each type of windstorm.

\subsubsection{Straight Winds}

a. Straight winds are non-rotating winds such as those found in thunderstorms. This type of wind data shall be collected for locations near the site. On-site data shall be collected, if available, and if they meet the following criteria:

- There shall be at least 10 continuous years of annual extreme wind speed records with elevations at which they were obtained.

- The type of wind speed recorded over time shall be specified (e.g., fastest mile, peak, etc.,).

- The recorded wind speeds shall be obtained from anemometers located in flat, open terrain.

- The elevations at which wind speeds are recorded shall be $10 \mathrm{~m}$ (33 feet) above ground.

b. If the last two conditions are not met, the recorded wind speeds shall be corrected using accepted wind boundary layer conversion methods. It is possible to utilize data from on-site stations for which less than 10 years of records exist if there are a sufficient number of historical records from nearby stations, within the same topographic environment.

c. In absence or lack of sufficient on-site wind record data, it is possible to utilize data collected by federal agencies for stations close to the site (generally within $50 \mathrm{~km}$ ) and located in a same wind environment (stations close to but separated by mountainous ranges from the site do not qualify). Such data have been collected at 129 weather stations (Simiu et al., 1979) within the continental U.S. and at coastal locations (Changery, 1985). In addition, wind speed records for more than 400 stations can be retrieved from the National Climatic Center. 


\subsubsection{Hurricane Winds}

a. Hurricane winds are rotating winds which can top $240 \mathrm{~km} / \mathrm{hr}(150 \mathrm{mph})$. Hurricane-prone regions of the continental U.S are located along the coastal areas. There are very few wind speed records from hurricane at coastal locations (Changery, 1985). Therefore, for sites in hurricane-prone areas and for which no up-to-date site-specific probabilistic hurricane wind hazard analysis has been performed in accordance with DOE-STD-1023-94, the meteorological data of past historical hurricanes within $400 \mathrm{~km}$ (250 miles) from the site shall be collected, which include:

- Track locations (longitude and latitude) with landfall locations,

- Intensity.

- Reported minimal central pressure near the coast or at landfall points,

- Reported maximum wind speeds near the coast or at landfall point, and

- Reported forward velocity and direction near the coast or at landfall point.

b. Systematic sources of data on hurricanes are available from the National Hurricane Center of Miami and the National Severe Storm Center and the Meteorological Society of America.

\subsubsection{Tornado Winds}

a. Tornado winds are violently rotating winds which can reach speeds in excess of $320 \mathrm{~km} / \mathrm{hr}(200 \mathrm{mph})$. Midwestern states, especially Oklahoma and its neighboring states have the greatest number of historically recorded tornadoes.

b. For sites containing facilities with SSCs in only Performance Category 1 or 2, tornado data need not be considered. For sites containing facilities with SSCs in Performance Category 3 or 4 , and for which no up-to-date site-specific probabilistic tornado wind hazard analysis has been performed in accordance with DOE-STD-1023-94, the following data shall be collected for tornadoes striking within $500 \mathrm{~km}$ (310 miles) from the site:

- Tornado track (latitude and longitude),

- Intensity, and

- Length and width.

c. Systematic sources of data on tornadoes are available from the National Severe Storms Forecast Center and the National Oceanographic and Atmospheric Administration. 


\subsubsection{Precipitation and Snowfall Data}

a. For sites containing facilities with SSCs in only Performance Category 1 or 2 , it is sufficient to utilize model building codes or national consensus standards, or rainfall intensity frequency-duration curves from hydrometeorological reports from the National Weather Service.

b. For sites containing facilities with SSCs in Performance Category 3 or 4, and for which no up-to-date site-specific probabilistic flood hazard analysis has been performed in accordance with DOE-STD1023-94, the following data shall be collected:

- Monthly and annual summaries (including averages and extremes) of precipitation at or near the site.

- Monthly and annual summaries (including averages and extremes) of snowiall and water contents at or near the site.

\subsection{HYDROLOGY}

a. The sources of hydrologic hazard include stream flooding, flood runoff, flood drainage, dam failure, levee or dike failure, storm surge, tsunami, seiche, wave action, volcano-induced hydrologic effects (e.g., rapid snow pack melting, mudflows to cause dam failure and excessive siltation/sedimentation), and ground water rise or decline. Collection of the characteristic data of these sources which could impact the site shall be performed. The impact of these hydrologic hazards shall be defined with respect to their proximity of the site and its elevation.

b. The extent of the data to characterize potential sources of flooding is dependent upon the performance categories of the structures. For sites containing facilities with SSCs in Performance Category 1 or 2, it is sufficient to utilize results of previous site-specific probabilistic flood hazard studies (e.g., McCann and Boissonnade, 1988a, 1988b, and 1991), if available, or to utilize information provided in the flood insurance studies by Federal Emergency Management Agency (FEMA) and any other reliable hydrology resource as listed in Paragraph 5.3.1.f.

c. For sites containing facilities with SSCs in Performance Category 3 or 4, and for which no site-specific probabilistic flood hazard studies have been performed in accordance with specifications in DOE-STD1023-94, site-specific characterization criteria are provided in the following paragraphs. 


\subsubsection{Hydrological Data Collection}

a. The location, size, shape, and other hydrologic characteristics of streams, lakes, shore regions, and ground water environment influencing the site shall be described. In addition, there shall be a quantitative description of existing and planned water control structures that may influence the hydrologic conditions at the site.

b. The hydrologic events which are potential sources of flooding for the site should be determined. The hydrologic events considered shall include:

Hydrologic Events.

- River Flooding

- Dam Failure

- Levee or Dike Failure

- Flcod Runott/Drainage

- Tsunami

- Seiche

- Storm Surge

- Wave

- Ground Water

- Mudflows

- Subsidence-indured Flooding Sources

Precipitation, snow melt, debris jams, ice jams, rapid sedimentation (volcano)

Earthquake, flood, volcano, landslide, static failure

Earthquake, flood, static failure, upstream dam failure, landslide, volcano

Precipitation, ponding, drainage capacity

Earthquake

Earthquake, wind

Hurricane

Wind, Tsunami

Precipitation, ponding, flooding, drought and over pumping

Volcano, earthquake

Fluid extraction (e.g., Gulf Coast, Sacramento Valley, etc.,)

c. The necessary hydrologic event data shall be collected to determine the flood sources and used to evaluate potential flood hazards at the site.

d. This data collection process is iterative. Initial data requirements focus on the need to identify potential sources of hydrologic hazards to the site. For each flood hazard a summary of hazard characteristics shall be provided. Only the worst case flood hazard should be summarized in detail. The summary shall include the proximity of the potential source of flood hazard to the site and include applicable reasons why certain sources are unlikely or present negligible consequences for the site. 
e. For hydrologic events that can pose a hazard, additional data shall be required to pertorm hazard assessment. Data sources should include, but not be limited to:

- Walkdown of site and vicinity

- Topographic maps (site-specific and regional)

- Aerial photographs

- Hydrologic data (i.e., stream gage data)

- Historical flood events reports

- Federal Emergency Management Agency's flood insurance studies

- Dam break studies

1. Tire sources of available data include past site-specific hydrological studies by DOE and DOE. sponsored contractors, studies performed by other government agencies (e.g., U.S. Army Corps of Engineers, U.S. Bureau of Reclamation, U.S. Geological Survey, Flood Insurance Administration, Department of Water Resources, Agricultural Department, National Weather Service, etc.,), universities, and private organizations.

g. Sections 5.3.2 to 5.3.11 provide criteria needed to define site specific information for each hydrologic event.

\subsubsection{Flood History}

a. Local and regional flood history with potential causes of flooding under extreme conditions shall be reported with date, level, peak discharge, and related information. A flood is defined as an abnormally high water stage or overflow from a stream, floodway, lake, or coastal area. This includes river floods, surges, seiche, tsunami, dam failures, ice or debris jams, and floods induced by landslides or similar events. Safety-related structures should not be built on a floodplain unless this is absolutely necessary.

\subsubsection{River Flooding}

a. Each river in the regional area of the site that could impact the site shall be identified and characterized with respect to its location and elevation relative to the site. 
0 . The boundaries of the region to be investigated for river flooding hazard depends primarily whether the rivers could cause floods large enough under extreme conditions to contribute to flooding at the site. Regional investigations shall be conducted for rivers relatively close to the site (in general, rivers with flood plain boundaries less than a few kilometers from the site).

c. For rivers which could be potential sources of site flooding, the potential for flooding shall be characterized by collecting the following information:

- Location and elevation of the rivers at the location closest to the site,

- Historical records of stream flow data (maximum yearly peak discharge and stage elevation) with recording location,

- Probable maximum flood level, that may be expected from a combination of the most critical meteorological and hydrologic conditions,

- Characterization of the geometric and hydraulic properties of the channel closest to the site. The geometric properties of the channel include Manning's roughness coefficient and top-width elevation tables for cross sections, and streambed slope.

- For sites with poor or inadequate nistorical data, results of paleoflood analyses should be provided for sites containing facilities with SSCs in Performance Category 4 if there is a potential of flood at the site.

- Presence of bridges or natural river flow constrictions which could cause flooding due to ice or debris jams.

d. For rivers for which no peak discharge records are available, the following information shall be gathered:

- Characteristics of the watersined basins of the river,

- Properties of the drainage basins including topographic maps of the basin and land cover maps.

\subsubsection{Dam, Levee, or Dike Failure}

a. Historic experiences and analytical studies indicate that floods associated with a dam break can significantly exceed flood levels that occur due to natural events. All dams upstream on rivers in the regional area of the site shall be identified and their characteristics summarized. These characteristics include: dam name, owner of dam, type of dam (e.g., earth fill, concrete, etc.,), year of completion, river name and location (e.g., river mile), total height, capacity, and closest distance from the river to the site. 
b. For dams that could pose a threat to the site should they fail, a detailed collection of data shall be conducted. Failures of dams that could pose a hydrologic hazard to the site include dams close enough to the site with relatively large storage capacity or distant dams with large storage capacity. The collection of data includes collecting existing dam break studies or data necessary to perform dam break analyses.

c. For dams for which dam break studies have been conducted as part of dam safety emergency management planning evaluations, results of these studies shall be collected, including date of study, Jam failure scenario (e.g., flood, earthquake, static failure due to internal erosion), peak discharge and elevation at closest point from site.

d. For dams for which no dam break studies are available or for which dam break studies are unavailable for all the potential hazards (seismic, flood, landslide, upstream dam failure), data shall be collected to conduct such studies.

e. The data to be collected include data necessary to perform a river flooding hazard analysis of the river reach upstream of the dam and/or upstream dams, seismic hazard analysis, potential landslide hazard analysis of the embankment or the dam itself, and dam break analysis. These data include:

- Results of seismic hazard analysis (Section 5.4),

- Data necessary to perform upstream river flooding hazard analysis (Section 5.3.3),

- Data on dam and dam characteristics, such as that described in Section 5.5, necessary to evaluate its resistance to the seismic loads and overtopping. These data include the material properties of the dam and abutment, characteristics of gates and other mechanical equipment which could affect the dam performance,

- Reservoir depth, length and storage elevation tables,

- Manning's roughness coefficient, and top-width elevation tables for downstream cross sections,

- For overtopping events the depth of overtopping at which failure occurs,

- In the case of hydrologic events, an inflow hydrograph, and

- Outflow characteristics for emergency spillway, outlets, and turbines.

\subsubsection{Storm Surge}

a. For sites located within regions that experience hurricanes or strong storm squalls and which are located close to large bodies of water, data on surges associated with such storms shall be collected from available flood hazard analyses. 
b. For cases where no such data are available, data necessary to perform joint probability hurricane frequency hazard analysis (e.g., Ho et al., 1987) shall be collected along with data on bathymetric characteristics of the coastline (depth tables), tide levels, and local topographic data between the site and large bodies of water.

c. The data necessary to perform joint probability hurricane frequency hazard analysis are specified in Section 5.2.2.2.

\subsubsection{Tsunami}

a. Tsunamis are ocean waves generated by vertical sea-floor displacements associated with large ottshore earthquakes. Such earthquakes may be those occurring close to a site or at great distances from a site. For sites located near an ocean, seismic data shall be collected to assess the potential for off-shore earthquakes which could create tsunami. Data collected shall include historical records of tsunami occurrence in the site region. Should potential for tsunami exist, local topographic data between the site and the ocean shall be collected and evaluated. Paleo data should be collected for sites containing facilities with SSCs in Pertormance Category 4 in case of no historical records of tsunami available at the site.

\subsubsection{Seiche}

a. Seiches are undulations of the surface of a body of water such as a bay, lake, or reservoir, set up by interaction of the water body with seismic forces, winds, and atmospheric pressure. For sites located near large bodies of water, seismic and meteorologic data shall be collected to assess the potential of creating seiche effects. Should this potential exist, local topographic data between the site and large bodies of water shall be collected and evaluated.

\subsubsection{Wave Action}

a. For sites located near bodies of water and in regions exposed to extreme winds, wind data shall be evaluated to assess the wave action. Should this hazard exist, water depths, fetch characteristics, and local topographic data between the site and large bodies of water shall be collected and evaluated. 


\subsubsection{Landslide and Volcano Created Natural Hydrological Consequences}

a. Land sliding into a river can dam the river and pose a flooding hazard upstream within the impoundment area or downstream in the event of overtopping of the dam. Tectonic uplift can have a similar damming effect. Volcanic eruption debris can create natural dams in narrow valleys and potential flood hazards. Volcanic enuption may also be causes of mudflows, rapid sedimentation in river, and rapid snowmelt, thus, to create potential flood hazards. Stability of slopes whose failures may cause this hazard shall be investigated. For regions with potential volcanic activity, topographic data shall be collected to indicate the likely locations of valley damming which could impact the site.

\subsubsection{Flood Runoff/Drainage}

a. Intense precipitation or snow melt may create local ponding or overland flooding when the soil infiltration capacity is exceeded. In addition, drainage capacity may be exceeded creating additional flooding.

b. The data to be collected are the local topographic characteristics of drainage areas including depressions, terrain slope, nature of soil vegetation or Manning's coefficients, and soil infiltration indices.

c. Data characteristics on precipitation and snowfall are provided in Section 5.2.3.

\subsubsection{Ground Water Hydrology}

a. Intense precipitation or snow melt and infiltration can cause ground water to rise and eventually to flood sites. For sites with shallow ground water tables, data on regional and local aquifers shall be collected, including formations and sources of the aquifers, local well log records, and drainage capacity.

b. Over pumping, reduced recharge and droughts can cause significant declines in ground water levels. This can lead to land subsidence and well failure. For sites that use ground water for production, cooling, or human consumption, or may be subject to land subsidence, record shall be kept of ground water level trends on a quarterly (minimum) basis. The water-level data should be adequate to document any long-term safety or environmental effects of ground water withdrawal. 


\subsection{GEOLOGY AND SEISMOLOGY}

a. The seismic-related hazards include site earthquake ground shaking, tectonic site deformation (fault rupture and associated tectonic surface deformation), ground failure induced by ground shaking including liquefaction, differential compaction and land sliding, and earthquake-induced flooding. Other geological hazards to be addressed include non-tectonic site deformation and volcanic hazards.

b. The extent of the investigation to characterize the seismic-related hazards is dependent upon the performance categories of the structures, the geological and seismologic environment of the site region, and the local soil conditions at the site. Geologists, seismologists, geophysicists, and geotechnical engineers with the knowledge and experience of fulfilling the requirements stated in the Federal Regulations and Standards (e.g., 10 CFR 100 Appendix A, NRC DG-1015, DOE 6430.1A, DOE 5480.28, etc.,) for site characierization for DOE facilities should be consulted for defining the program of the investigation. Site experts who are knowledgeable of geological, seismological, and geotechnical aspect of site characterizations should also be consulted.

c. For sites containing facilities with SSCs only in Performance Category 1 or 2 , it is sufticient to utilize results of previous site-specific probabilistic seismic hazard studies, if available, or to utilize information provided in the model building codes or national consensus standards (e.g., seismic zone maps). For sites containing facilities with SSCs in Performance Category 3 or 4 , and for which no site-specific probabilistic seismic hazard studies have been performed in accordance with DOE-STD-1023-94, sitespecific characterization criteria are provided in the following paragraphs.

\subsubsection{Seismic Sources}

a. Seismic sources define areas where future earthquakes are likely to occur. All Seismic sources in the site region that could cause significant ground shaking at the site shall be identified and characterized. Seismic sources may include seismogenic sources and capable tectonic sources. A seismogenic source is a portion of the earth which is considered to have uniform seismicity. A seismogenic source may be a well-defined tectonic structure or simply a large region of diffuse seismicity. A seismogenic source would not cause surface displacement. A capable tectonic source is a tectonic structure which can generate both earthquakes and ground deformation. Geological, geophysical and seismological investigations provide the information needed to identify and characterize source parameters, including the location, size, and geometry of the seismic sources, maximum earthquake, and frequency of occurrence of earthquakes of various magnitudes (earthquake recurrence). 
b. The potential for fault rupture and associated tectonic surface deformation at the site (e.g., tilting or folding) shall also be evaluated. The amount and style of deformation and the likelihood of future displacement shall also be characterized for any Quaternary (approximately last 2 million years) faults in close proximity to the site (within about $8 \mathrm{~km}$ or 5 miles).

\subsubsection{Seismic source identification data}

a. All seismic sources that could contribute significantly (more than 5 percent to the total hazard) to a probabilistic ground motion assessment, as described in DOE-STD-1023-94, shall be identified and characterized with respect to their location and geometry relative to the site. The following items shall be considered in collecting data for seismic source identification:

1. Area of investigations. The boundaries of the region to be investigated for seismic hazards depend primarily on whether distant seismic sources could cause earthquakes large enough to govem or contribute significantly to the ground motion at the site and the performance category of facility SSCs within the site. The sizes of the regions to be investigated should be large enough to adequately characterize the hazards that can affect the site. The choice of an area and justification of that choice is the responsibility of the investigator. The results of a scoping hazard study may be utilized to aid in determining the area of investigation of the site. If such a study clearly shows that the near site features dominate the hazard, more extensive site investigations should be made in the near field. U.S. NRC NUREG-1451 (McConnell et al., 1992) provides an iterative approach for identification of the regions to be investigated to identify fault displacement hazards and seismic hazards at a geologic repository in the Western United States (WUS) based on a review of the pertinent literature, relevant field invistigations, and consideration of alternative tectonic models. For investigations of sites containing facilities with SSCs in Performance Category 4 such as nuclear reactor safety, U.S. NRC Regulatory Guide DG-1015 (USNRC, 1992a) provides guidance for identification of the regions to be investigated:

- Regional investigations using literature reviews and geological reconnaissance should generally be conducted for a radius of $320 \mathrm{~km}$ (200 miles) from the site, unless clearly justified.

- Geological, seismological, and geophysical investigations should be carried out for a radius of $40 \mathrm{~km}$ (25 miles) from the site to identify and characterize the seismic and surface deformation potential of seismic sources, or to demonstrate that such structures are not present.

- Detailed geological, geophysical, seismological, and geotechnical (GGSG) investigations should be conducted for a radius of $8 \mathrm{~km}$ ( 5 miles) from the site to determine the potential for surface tectonic and non-tectonic deformations in the site vicinity.

- The area of detailed GGSG investigations may be larger than a 5-mile radius in regions of late 
Quatemary earth movements or historical seismic activities, or where a site is located near a fault zone, or complex geology.

2. Type of investigations. There are several acceptable types of investigations to identify seismic sources. Different techniques are required depending on the geologic setting and tectonic environment. In most cases, more than one approach must be used and the reliability of the results depends on the experience and competence of the investigators for synthesizing and interpreting various types of geological, seismological, and geophysical data. Types of investigations include:

- Analysis of aerial photographs and other remote sensing imagery

- Geologic, including stratigraphic and structural, reconnaissance and mapping

- Geomorphic analysis (e.g., fault scarp morphology, terrace profiling, geodetic land surveys)

- Analysis of local and regional geophysical data (e.g., seismic reflection, seismic refraction, aeromagetics, gravity, etc.,)

- Subsurface investigations of suspected fault traces (e.g., trenching, geophysical investigations, borings)

- Age dating techniques including radiometric (e.g., carbon 14, thermoluminescence), chemical (e.g., pedogenic soils), biological (dendrochronology), and evolutionary (palynology)

- Listing of all historically reported earthquakes (including instrumentally recorded data) that are associated with seismic sources, any part of which is within a radius of $320 \mathrm{~km}$ (200 miles) of the site, and seismicity analysis, including date of occurrence, earthquake sizes (intensity and/or magnitude), epicantral locations, focal depths, and focal mechanisms

- Correlation of seismicity with geologic structure

- Interpretation of stress orientation from focal mechanisms, geologic indicators, field experiments (e.g., hydrofracturing, borehole breakout investigations), and geodetic data

3. Source zones. In the stable continental region of the Eastem U. S. (EUS), away from tectonic plate margins, it generally has not been possible to associate seismicity with specific geologic structures. Historic or prehistoric EUS earthquakes associated with specific geologic structures have been identified in only a few instances (e.g., Meers fault in Oklahoma). Thus, in the EUS, earthquake sources are usually defined for ground motion analyses as source zones (areas or volumes of the earth's crust) having uniform earthquake potential (uniform earthquake recurrence and uniform maximum earthquake magnitude throughout the area). Typically, source zones are defined primarily on the basis of the spatial distribution of observed seismicity complemented by information on the regional geologic structure and tectonics. Such source zones also exist in the Western U.S. (WUS) in areas of lower seismicity and alluvial valleys where active faults have not been identified. 
4. Active faults. As defined in NRC DG-1015, an active fault is part of capable tectonic source which is essentially characterized by the presence of surface or near surface deformation of geologic deposits of a recurring nature within the last approximately 500,000 years or at least once in the last approximately 50,000 years or/and an association with one or more large earthquakes or sustained earthquake activity which are usually accompanied by significant surface deformation. All Quarternary faults within about 25 to $50 \mathrm{~km}$ of a site should be assessed to determine if they are significant contributors to the seismic hazard of the site. Detailed site characterization is necessary for active faults within a radius of $8 \mathrm{~km}$ (5 miles) of a site as input to the probabilistic seismic hazard analysis and the vibratory ground motion estimation. In the WUS, the focus of seismic source identification is on identifying active faults or fault-related features (such as fault-related anticlinal folds) that are observed at the ground surface. This focus is appropriate because large earthquakes (historic and prehistoric) typically have occurred on mapped active faults in the WUS. It is also appropriate to define seismic source zones in the WUS to incorporate that portion of the seismicity (typically small-to-moderate-magnitude earthquakes) that does not appear to be associated with identified discrete faults. The geological, seismological and geophysical investigations to identify the locations and geometry of faults that may be significant seismic sources shall, to the extent practical, address the following factors:

- Rate of Fault Movement. In evaluating the rate of fault movement, the following factors must be considered: historical and geologic evidence regarding the displacement history (especially the Quaternary displacements) of the fault, historical and instrumental seismicity data, structural relations that may suggest kinematic linkages to a known active fault, and the regional tectonic setting.

- Sense of Slip (style of faulting). For cases in which a fault has experienced slip in more than one direction during its history, emphasis should be on assessing its most recent slip sense. The horizontal and vertical components of displacement and at least a general assessment of the fault dip are required to properly classity the sense of slip on a fault.

- Fault Dip and Down dip Width. To model fault sources in three-dimensions, an assessment must be made of the dip of the fault throughout the seismogenic crust. The down dip width of a fault can be assessed indirectly based on the estimated maximum depth of the seismogenic crust and the dip of the fault source. Example approaches to determine the angle of dip are: (1) Use geometry of foreshock/aftershock earthquake foci to define fault plane orientation; (2) Seismic reflection profiles, where available; and (3) Details of outcrop patterns along range-front.

- Buried or Blind Faults. Blind potential seismic sources can be identified by a combination of subsurface interpretations (e.g., balanced cross sections, seismic reflection) coupled with evidence for geologically-young deformation (e.g., folding of Quaternary deposits and surfaces). As an example, the location and dimensions of an interpreted blind thrust ramp are important to the assessment of the maximum magnitude that the ramp may be capable of generating, and the rate of 
slip will be important to estimating recurrence.

- Fault Segmentation. Fault zones usually consist of individual fault segments. Fault segmentation provides a means for estimating the expected length of fault ruptures. The locations of fault segments and the boundaries between segments shall be evaluated.

5. Source-to-site distance. The factors described above, which govern the location and geometry of seismic sources, provide the basis for establishing the distance between the site and the earthquake source. The measure of the source-to-site distance used in the seismic hazard analysis (e.g., epicentral distance or closest distance to the fault rupture surface) may vary depending upon the procedure used to estimate earthquake attenuation effects.

\subsubsection{Seismic source characterization}

a. For deterministic ground motion analysis, maximum earthquake magnitudes must be assessed for the governing seismic sources. For probabilistic ground motion analysis, both maximum earthquake magnitudes and earthquake recurrence shall be assessed for all seismic sources that contribute significantly to the probability of exceeding ground motion levels at the site for the performance category of the facilities. The ranges of potential seismic sources and the uncertainties in seismicity parameters should be defined as required in DOE-STD-1023-94.

b. The characteristics of a seismic source may include:

- Source zone geometry (location and extent, both surface and subsurface),

- Description of Quatemary displacements (sense of slip on the fault, fault dimensions, age of displacement, estimated displacement per event, estimated magnitudes per offset, rupture length and area, and displacement history or uplift rates of seismogenic folds),

- Historical and instrumental seismicity associated with each source,

- Paleoseismicity,

- Relationship of the fault to other potential seismic sources in the region,

- Maximum earthquake the source would be capable of producing,

- Recurrence model (frequency of earthquake occurrence versus magnitude).

c. Maximum earthquakes are usually assessed in two principal ways:

1. Estimate the maximum dimensions of future ruptures and relate those dimensions to magnitude. This approach, which is geared toward characterizing the dimensions of faults, is commonly applied in the WUS. The dimensions of ruptures and/or amount of displacement that might be expected on 
a fault of interest are estimated from geologic investigations designed to assess what has occurred during past ruptures. As many of the rupture dimensions as possible should be used to lend stability to the magnitude estimates. Also, the uncertainties in the values of the rupture parameters should be incorporated (e.g., National Research Council, 1988; Coppersmith and Youngs, 1986; 1990)

2. Consider the size of historical earthquakes associated with the source and with tectonicallyanalogous sources. However, this approach should only be applied after it has been shown that the approach commonly used in the WUS as described above is not applicable. Common acceptable approaches used in assessing maximum earthquakes in the Eastern United States (EUS) are: (1) lake the source zone's maximum historical earthquake as the maximum; (2) take the maximum historical earthquake and add an arbitrary magnitude (or intensity) increment to it; or (3) draw an analogy to another source zone and use the maximum historical earthquake associated with that. source. The maximum earthquakes can also be evaluated based on the opinions provided by a panel of experts with knowledge of the site region (Bernreuter et al., 1989; Coppersmith and Youngs, 1990).

d. Probabilistic seismic hazard analysis also requires the specification of the recurrence or frequency of occurrence of earthquakes of various magnitudes; each seismic source requires its own recurrence relationship. For large areal source zones, historical seismicity data are usually used to estimate earthquake recurrence rates. However, observed seismicity is usually insufficient to characterize adequately the recurrence curve for a given source throughout the range of magnitudes up to the maximum. It is important to correct the earthquake catalog for completeness of seismicity data to be used for probabilistic seismic hazard analysis. The following geological data shall be used to estimate the repeat times for large events:

- Geologic recurrence intervals. The geologic record captures the occurrence of earthquakes by recording direct stratigraphic displacements within the fault zone; uplift, subsidence, or other tectonic deformation; or secondary effects related to seismic shaking such as liquefaction and land sliding.

- Fault slip rate. Fault slip rates, derived from the amount of slip that has occurred over a geologicallydefined interval, can be used to estimate average earthquake recurrence rates. Slip rates are determined by assessing the amount of fault displacement of a geologic unit having a known age.

- Temporal clustering. Earthquakes occurring on a seismic source may be clustered in time. The potential effects of temporal clustering on estimated recurrence rate should be considered. 


\subsubsection{Surface-fault rupture and associated deformation}

a. A site location that has a potential for surface-fault rupture and associated deformation from active faults should be avoided. Where it is determined that surface deformation need not be taken into account, sufficient data or detailed studies to clearly justify the determination should be presented.

Requirements for setback distance from active faults for hazardous waste treatment, storage, and disposal facilities can be found from Environmental Protection Agency regulation (40 CFR 264).

b. The presence or absence of Quatemary faulting at the site needs to be evaluated to determine if there is a potential hazard due to surface faulting. The potential for surface fault rupture should be characterized by evaluating: (1) the location and geometry of faults relative to the site; (2) nature and amount of displacement (sense of slip, cumulative slip, slip per event, and nature and extent of related folding and/or secondary faulting); and (3) the likelihood of displacement during some future period of concern (recurrence interval, slip rate, and elapsed time since the most recent displacement).

c. For assessing the potential for fault displacement, the details of the spatial pattern of the fault zone e.g., the complexity of fault traces, branches, and en echelon patterns) may be important as they may define the particular locations where fault displacement may be expected in the future. The amount of slip that might be expected to occur can be evaluated directly based on paleoseismic investigations or it can be estimated indirectly based on the magnitude of the earthquake that the fault can generate.

\subsubsection{Vibratory Ground Motions}

a. After seismic sources in the region of a site are defined, vibratory ground motions at the site can be estimated using criteria that are specified in DOE-STD-1023-94. The vibratory ground motions are generally defined by the horizontal and vertical response spectra corresponding to the expected ground motion at the free-field ground surface. The estimate of vibratory ground motions at the site should be based on a detailed evaluation of the earthquake potential taking into account regional and local geology, tectonics, seismicity, as well as specific local soil conditions.

b. In general, the factors that influence site ground motions include the characteristics of the earthquake source, the travel path between the source and the site, and the local site conditions. Assessment of the influence of local soil conditions is described in Section 5.5.2. The attenuation effect of the geological materials in the travel path (e.g., $Q$ factor) shall be estimated by regional seismology studies or based on the strong ground motion data, if a sufficient data base is available. The effect of local geology and rock conditions on the ground motions shall also be considered. With respect to the first two factors (i.e., earthquake source and travel path), it is suggested that one or both of these factors 
can result in significant differences in earthquake ground motions in three broad tectonic regimes in the United States -- the Central and Eastern U.S. (EUS), Western U.S. (WUS), and areas in the vicinity of subduction zones. Precise geographic limits for the regions are not defined, but the WUS and EUS are generally west and east, respectively of the Rocky Mountains, while subduction zone earthquakes in the United States occur only along coastal northwest California, Oregon, Washington, and southern Alaska. Based on recent ground motion study by Electric Power Research Institute (EPRI, 1993), the EUS area can be further subdivided into the Mid-continent and the Gulf Coast regions. Different attenuation relationships would thus be appropriate for each region. Thus, care must be taken and uncertainties must be recognized in utilizing data bases, relationships, and methodologies applicable to each region.

c. In the WUS, particularly coastal Califomia, relatively well-constrained attenuation relationships (i.e. relationships between earthquake magnitude, source-to-site distance, and ground motion amplitude. e.g. Boore et al., 1993; Joyner and Boore, 1988; Campbell, 1985; Boore and Joyner, 1982) have been developed from a data base of abundant strong ground motion recordings from shallow crustal earthquakes. Estimates of site ground motions for shallow crustal earthquakes in the WUS can be made using these attenuation relationships or through appropriate statistical analyses of strong ground motion data sets. If ground motion estimates are required for particular combinations of source geometry, earthquake size, and/or crustal structure that are not represented in the empirical data, theoretical/numerical ground motion modeling techniques can be used to evaluate various source and path effects and extend the empirical models beyond the limits of the recorded data.

d. In the EUS, there are relatively few strong ground motion recordings, particularly for larger magnitude earthquakes. Empirical ground motion attenuation relationships can be developed by using ground motion recordings from the EUS enhanced by recordings from other regions of the world similar to the EUS. Attenuation relationships can also be obtained on the basis of theoretical/numerical ground motion models. Since there are limited calibration and verification from ground motion data for these models, the greater uncertainty involvec shall be recognized in using the attenuation relationships. Under certain circumstances (for example, in the near-source region where differences in travel path effects between the EUS and WUS may not be significant), it may be appropriate to utilize the WUS ground motion data base in making ground motion estimates for EUS sites. However, this should be done $r$. ognizing the limitations and uncertainties. EUS ground motion estimates made on the basis of WUS data may be deficient in high frequency ground motions, and an appropriate correction must be used to account for these high frequency deficiencies. The WUS versus EUS correction factors may be developed using stochastic ground motion models as well as using available EUS and WUS data for generic site categories. Comparison of empirical Western North America (WNA) amplification factors for deep stiff soil to computed factors for Eastern North American (ENA) can be found in 
Guidelines for Determining Design Basis Ground Motion (EPRI, 1993).

e. There are considerable ground motion data from subduction zone earthquakes, and attenuation relationships specific to subduction zone environments have been developed from this data base (Crouse, 1991; Youngs et al., 1988; Langstom, 1981). The relationships can also be developed from a combination of empirical data and data simulated with theoretical/numerical models (Wong et al., 1993; Heaton and Hartzell, 1989; Ihnen and Hadley, 1986). In general, attenuation relationships for ground motions from subduction zone earthquakes are less constrained by data and more uncertain than for shallow crustal earthquakes in the WUS. Because there is a great deal of scatter in the data, the variability should be quantified in the estimate of vibratory ground motion at the site.

\subsubsection{Earthquake-Induced Flooding}

a. Earthquake-induced flooding at a site can be caused by a variety of phenomena including seiches, tsunamis, failures of dams and levees, land sliding within or into bodies of water, and tectonic uplift or subsidence. Criteria of site characterization for these hazards are specified in Section 5.3.

b. The investigation of a potential earthquake-induced flooding hazard involves assessing either or both of (1) whether there is any exposure of a facility to a flooding hazard (e.g., whether a facility is located adjacent to a body of water, located downstream of a dam, etc.,) and (2) whether there is a significant likelihood of the hazard occurring to a degree sutficient to cause flooding of the facility site (e.g., whether there is significant risk of a tsunami wave high enough to cause flooding, significant risk of a dam failure, etc.,). The assessment of earthquake-induced flooding hazards may require involvement of disciplinary expertise other than geology and seismology, such as coastal engineering in the case of tsunami phenomena and geotechnical and structural engineering in the case of potential for dam failure.

\subsubsection{Other Geologic Hazards}

a. Other geologic hazards that should be the subject of appropriate geological investigations include volcanic hazards and non-tectonic surface deformation.

\subsubsection{Volcanic hazards}

a. Recent volcanic activity is restricted to limited areas of the Western United States. In most places, volcanism does not pose a significant hazard. In regions where recent volcanic activity (Quarternary) has occurred, the likelihood of renewed volcanic activity and the associated potential hazards shall be 
assessed. Potential volcanic hazards may include: lava flows, ballistic projections, tephra (ash) falls, pyroclastic flows and debris avalanches, lahars and flooding, seismic activity, ground deformation, tsunami, atmospheric effects, and acid rains and gases. Discussions on assessment of volcanic hazards are given by Hoblitt et al. (1987), Tilling (1989), and Lawrence Livermore National Laboratory (1990). The DOE Standard for volcanic hazard assessment is not yet available. For those few sites need volcanic hazard assessment, their approach used to assess volcanic hazards should be approved by DOE.

\subsubsection{Non-tectonic surface deformation}

a. Non-tectonic phenomena that can result in surface deformation at a facility site include glacially-induced faulting, growth faulting, collapse due to underground voids such as found in Karst terrain, and subsidence due to extensive fluid withdrawal.

b. Glacially-induced faults generally do not represent a significant displacement hazard because the conditions that created them are no longer present. If residual stresses from pleistocene glaciation are still present. these features should be investigated with respect to their relationship to current in-situ stresses.

c. The existence of cavities in some geological materials (e.g. limestone, gypsum, anhydrtte, etc.,) may lead to ground collapse. If collapse features are present, they shall be considered and investigated with respect to their potential for causing deformation of the facility site and, if so, whether engineered stabilization measures are feasible.

d. Large, naturally occurring growh faults, as found in the coastal plain of Texas and Louisiana, can pose a surface displacement hazard even though offset most likely occurs at a slower rate than that of tectonic faults. They shall be identified and avoided in siting, and their displacements shall also be monitored. Some growth faults and antithetic faults related to growth faults are not easily identified; therefore, investigations of the potential amount and character of displacement shall be undertaken in regions where growth faults are known to be present.

\subsection{GEOTECHNICAL STUDIES}

a. Geotechnical studies may include investigations for: (1) defining site soil properties as may be required for hazard evaluations, and engineering analyses and designs; (2) assessing local soil site effects on ground motions; (3) carrying out soil-structure interaction analyses; and (4) assessing potential of soil 
failure or deformation induced by ground shaking (liquefaction, differential compaction, land sliding. etc.).

b. The extent of investigation to determine the geotechnical characteristics of a site depends on the pertormance categories of the facilities, the subsurface conditions, and the extent of available information. General requirements for site investigations and foundation design criteria can be found in DOE Order 6430.1A. "U.S. DOE General Design Criteria". For facilities with SSCs in Performance Category 4, the geotechnical studies shall include, at a minimum, the investigations specified in Sections 5.5.1 through 5.5.4. Reduced scope of investigation is allowed for sites containing facilities with SSCs in Pertormance Category 3 or lower, if the additional uncertainties resulting from the less extensive investigation are acceptable and justified based on analyses by the project team. By working with experienced geotechnical engineers and geologists, an appropriate scope of investigations can be developed for a particular facility.

\subsubsection{Site Investigations}

a. Site investigations shall be conducted for facilities if the site intormation is not available or insulficient for NPH assessment and design/evaluation of the particular facilities. Soil/rock profiles (cross-sections) at the locations of the facilities shall be provided based on the results of site investigations. The quantification of site soil/rock properties, such as classifications, strengths, compressibilities, densities, and wave velocities, is needed for engineering design, and evaluations of soil amplification, soilstructure interaction, potential for liquefaction, differential compaction, and land sliding. The properties required are intimately linked to the designs and evaluations to be conducted. For example, for analyses of soil response effects or soil-structure interaction, assessment of strain dependent soil dynamic modulus and damping characteristics are needed. An appropriate site investigation program shall be developed in consultation with the geotechnical engineering representative of the project team.

\subsubsection{Subsurface exploration}

a. Subsurface conditions shall be determined by means of borings, soundings, well logs, exploratory excavations, sampling, geophysical methods (e.g., crosshole, downhole, and geophysical logging) that adequately disclose soil and ground water conditions. Appropriate investigations shall be made to determine the contribution of the subsurface soils and rocks to the loads imposed on the structures subjected to NPH. 
b. The extent of subsurface investigations is dictated by the performance category of the facilities, by the foundation requirements, and by the complexity of the anticipated subsurface conditions. For sites containing tacilities with SSCs in Pertormance Category 3 and 4, the QA requirements should be extended to retrieving, transportation, handling and testing of soil samples. The locations and spacings of borings, soundings and exploratory excavations shall be chosen to adequately define subsurface conditions. Subsurface explorations shall be located to permit the construction of geological cross sections and soil profiles through foundations of safety-related structures and other important locations at the site. Sufficient geophysical and geotechnical data should be obtained to allow for reasonable assessments of representative soil profile and soil parameters.

\subsubsection{Laboratory tests}

a. A laboratory testing program shall be carried out to identify and classity the subsurface soils and rocks and to determine their physical and engineening properties. For evaluation and design of DOE facilities with SSCs in Pertormance Category 3 or 4, laboratory tests for both static and dynamic properties (e.g., shear modulus, damping, liquefaction resistance, etc.,) are generally required. The dynamic property lests may include cyclic triaxial tests. cyclic simple shear tests, cyclic torsional shear tests, and resonant column tests. Both static and dynamic tests shall be conducted as recommended in American Society for Testing and Materials (ASTM) standards or test procedures acceptable to the DOE. The ASTM specification numbers for static and dynamic laboratory tests can be found in the anriual books of ASTM Standards, Volume 04.08. Examples of soil dynamic property and strength tests are shown in Table 1. Sufficient laboratory test data should be obtained to allow for reasonable assessments of median values of soil properties and their potential variability.

\section{Inble 1. Examples of Soll Dynamic Property and Strength Tente \\ D 3999-91 Standard Test Method for the Determination of the Modulus and Damping Properties of Soils Using the Cyclic Triaxial Apparatus \\ D 4015-92 Standard Test Methods for Modulus and Damping of Soils by the Resonant-Column Method \\ D 5311.92 Standard Test Method for Load Controlled Cyclic Triaxial Strength of Soil}

b. For coarse geological materials such as coarse gravels and sand-gravel mixtures, special testing equipment and testing facility should be used, (e.g., University of California Rockfill Testing Facility, Ricmond, California). Larger sample size is required for laboratory test on this type of materials, (e.g., 
samples with 12-inch diameter were used in the Rocktill Testing Facility). It is generally difficult to obtaip in-situ undisturbed samples of unconsolidated gravely soils for laboratory tests. If it is not feasible to collect test samples and, thus, no laboratory test results available, the dynamic properties should be estimated from the published data of similar gravely soils.

\subsubsection{Site Response Analysis}

a. As part of the quantification of earthquake ground motions at a facility site, an analysis of soil response effects on ground motions may be needed. Note that a specific analysis is not required if the site is a hard rock site or if the subsurface soil conditions have already been adequately accounted for in the selection and use of strong motion data and attenuation relationships for subsurface conditions similar to those that exist at the site. For facilities with SSCs in Pertormance Category 1 or 2 , it is sufticient to comply with the criteria for ground motions specified in the model building codes although sufficient site-specific information is needed to select the proper site category.

b. Site response analyses (often referred to as site amplification analyses) are relatively more important when the site surticial soil layer is a soft clay and/or when there is a high stiffness contrast (wave velocity contrast) between a shallow soil layer and underlying bedrock because a few ground motion recording have been obtained for such conditions and have shown strong local soil effects on ground motion. Site response analyses are always important for those sites having predominant frequencies within the range of interest for the SSCs being evaluated. Thus, the stiftness of the soil and bedrock as well as the depth of soil deposit should be carefully evaluated.

c. In a site response analysis, the ground motions (usually acceleration time histories) defined at bedrock or outcrop are propagated through an analytical model of the site soils to determine the influence of the soils on the ground motions. The required soil parameters for the site response analysis include the depth, soil type, density, shear modulus and damping, and their variations with strain levels for each of the soil layers. Internal friction angle, cohesive strength, and over-consolidation ratio for clay are also needed for non-linear analyses. The results of the site response analysis shall show the input motion (rock response spectra), output motion (surface response spectra), and spectra amplification function. Criteria for developing the design response spectra are given in DOE-STD-1023-94.

d. The strain dependent shear modulus and damping curves should be developed based on sitespecific testing results and supplemented as appropriate by published data for similar soils. The effects of confining pressures (that reflect the depths of the soil) on these strain dependent soil dynamic characteristics should be assessed and considered in site response analysis. 


\subsubsection{Soll-Structure Interaction Analysis}

a. Soil-structure interaction (SSI) analyses shall be carried out when required to ascertain the influence of the interaction of the structure and the surrounding soil on the response of the structure to the defined site free field ground motions. Soil-structure interaction effects are more significant for heavy and/or embedded structures. Criteria for conducting SSI Analysis are provided in DOE-STD-1020-94.

b. The effect of soil-structure interaction should be considered for SSCs in Performance Category 3 and shall be performed for SSCs in Performance Category 4. SSI analyses shall use the design free-field ground motion as input. The same soil parameters specified in Paragraph 5.5.2.c shall be obtained for SSI analyses. Due to the uncertainty in the input ground motion as well as soil parameters and structural properties used in the SSI analysis a relatively wide range of soil shear moduli as required by ASCE Standard 4-86 (ASCE, 1986) and DOE-STD-1020 is recommended so that a conservative structure response calculation may be expected.

c. Dynamic soils properties can vary significantly depending on whether soil layers are saturated. For SSI analysis, unsaturated soil properties should be used for soil layers above the normal water table unless the site conditions indicate that additional soil saturation occurs frequently or for long durations.

\subsubsection{Ground Fallure Evaluations}

\subsubsection{Seismic liquefaction of Solls}

a. Liquefaction is a soil behavior phenomenon in which cohesionless soils (sand, silt, or gravel) under saturated conditions lose a substantial amount of strength due to high pore water pressures generated in the soils by strong ground motions induced by NPH, such as earthquakes or wave actions. Potential effects of liquefaction include reduction in foundation bearing capacity, settlements, land sliding and lateral movements, flotation of lightweight structures (such as tanks) embodded in liquefied soil, and increased lateral pressures on walls retaining liquefied soil. The general procedure for evaluations of liquefaction potential is given in the Appendix C of the EPRI Report "A Methodology for Assessment of Nuclear Power Plant Seismic Margin" (EPRI, 1988).

b. Investigations of liquefaction potential typically involve both geological and geotechnical engineering assessments. The parameters controlling liquefaction phenomena are: the lithology of the soil at the site, the ground water conditions, the behavior of the soil under dynamic loading and potential severity of the vibratory ground motion. The following site-specific data shall be acquired and utilized along with state-of-the-art evaluation procedures (e.g., Seed and Idriss, 1982; Seed et al., 1985): 
- Soll grain size distribution, density, static and dynamic strength, stress history and geologic age of the sediments,

- Ground water conditions,

- Penetration resistance of the soil, e.g., Standard Penetration Test (SPT), Cone Penetration Test(CPT),

- Shear wave velocity of the soil

- Evidence of past liquefaction,

- Ground motion characteristics.

c. A soll behavior phenomenon similar to liquefaction is strength reduction in sensitive clays. Although this behavior phenomenon is relatively rare in comparison to liquefaction, it should not be overlooked as a potential cause for land sliding and lateral movements. Therefore, the existence of sensitive clays at the site shall be identified.

\subsubsection{Subsidence}

a. Ground settlement during and after natural phenomena hazards due to dynamic loads, change of ground water conditions, soil expansion, soil collapse, erosion, and other causes shall be considered. Ground settlement due to the ground shaking induced by NPH can be caused by two factors: (1) compaction of dry sands due to ground shaking, and (2) settlement due to dissipation of dynamically induced pore water in saturated sands. Differential settlement would cause more damage to facilities than would uniform settlement. Differential compaction of cohesionless soils and resulting differential ground settlement can accompany liquefaction or may occur in the absence of liquefaction. The same types of geologic information and soil data used in liquefaction potential assessments, such as the Standard Penetration Test (SPT) N-value, can also be used in assessing the potential for differential compaction. Ground subsidence has been observed at the surface above relatively shallow cavities formed by mining activities (particularty coal mines) and where large quantities of salt, oil, gas, or ground water have been extracted, (Hatheway and McClure, 1979). Where these conditions exist near a site, consideration and investigation must be given to the possibility that surface subsidence will occur.

\subsubsection{Slope instablitity}

a. Stability of natural and man-made slopes shall be evaluated when their failures would affect the safety and operation of DOE facilities during natural phenomena hazards. In addition to land sliding facilitated by liquefaction-induced strength reduction, instability and deformation of hillside and embankment slopes can occur due to the ground shaking inertia forces causing a temporary exceedance of the 
strength of the soil or rock. The slip surfaces of previous landslides, weak planes or seams of subsurface materials, mapping and dating paleo slope failure events, loss of shear strength of the materials caused by the natural phenomena hazards such as liquefaction or reduction of strength due to wetting, hydrological conditions including pore pressure and seepage, and loading conditions imposed by the natural phenomena events shall all be considered in determining the potential for instability and deformations. Various possible modes of failure shall be considered. Both static and dynamic analyses shall be performed for the stability of the slopes.

b. The following information, at a minimum, shall be collected for the evaluation of slope instability:

- Slope cross sections covering areas which would be affected the slope stability,

- Soil and rock profiles within the slope cross sections,

- Static and dynamic soil and rock properties, including densities, strengths, and deformabilities,

- Hydrological conditions and their variations,

- Rock fall events, 


\subsection{REFERENCES}

American Society of Civil Engineers (1986), ASCE 4-86, Seismic Analysis of Safety-related Nuclear Structures and Commentary on Standard for Seismic Analysis of Safety-related Nuclear Structures, currently in process of updating.

American Society of Civil Engineers (1988), ANSI/ASCE 7-88, Minimum Design Loads for Buildings and Other Structures, ANSI approved Nov. 1990.

Bernreuter, D. L., et al. (1989), Seismic Hazard Characterization of 69 Nuclear Plant Sites East of the Rocky Mountains, NUREG/CR-5250, Lawrence Livermore National Laboratory, Livermore, CA.

Boore, D. M. and W. B. Joyner (1982), The Empirical Prediction of Ground Motion, Bull. Seism. Soc. Am. 72, 43-60.

Boore, D. M., W. B. Joyner, and T. E. Fumal (1993), Estimation of Response Spectra and Peak Acceleration from Western North American Earthquakes: An interim report, U.S. Geol. Surv. Open-File Rept. 903-509, 72 pp.

Building Officials and Code Administrators International (BOCA), National Building Code, 1992 Supplement.

Campbell, K. W. (1985), Strong Motion Attenuation Relations: A ten-year perspective, Earthquake Spectra 1, 759-804.

Changery, M. J. (1985) Historical Extreme Winds for the United States-Atlantic and Gulf of Mexico Coastlines, NUREG/CR-2639, National Oceanic and Atmospheric Administration.

Code of Federal Regulations (CFR), Title 10, Part 100, Appendix A, Criteria for the Seismic and Geologic Siting of Nuclear Power Plants.

Code of Federal Regulations (CFR), Title 10, Part 100, Appendix B, Criteria for the Seismic and Geologic Siting of Nuclear Power Plants on or after [Effective Date of this Regulation], draft under preparation. 
Code of Federal Regulations (CFR), Title 40, Part 264, Standards for Owners and Operators of Hazardous Waste Treatment, Storage, and Disposal Facilities.

Coppersmith, K. J. and R. R.. Youngs (1986), Capturing Uncertainty in Probabilistic Seismic Hazard Assessment within Intraplate Tectonic Environments, Proceedings Third U.S. National Conference on Earthquake Engineering, Earthquake Engineering Research Institute, 1:301-312.

Coppersmith, K. J. and R. R. Youngs (1990), Probabilistic Seismic-hazard Analysis Using Expert Opinion; An Example from the Pacific Northwest, in E. L. Krinitzsky and D.B. Slemmons, Neotectonics in Earthquake Evaluation. Geological Society of America Reviews in Engineering Geology, 8, 29-46.

Crouse, C. B. (1991), Ground motion attenuation equations for earthquakes on the Cascadia subduction zone, Earthquake Sprectra 7, 201-236.

Electric Power Research Institute (1988), A Methodology for Assessment of Nuclear Power Plant Seismic Margin, Appendix C, EPRI NP-6041 Final Report, October 1988.

Electric Power Research Institute (1993), Guidelines for Determining Design Basis Ground Motions, Vol. 1; Method and Guidelines for Estimating Earthquake Ground Motion in Eastern North America, EPRI TR-102293, Final Report, November, 1993.

Hatheway, A. W. and C. R. McClure (1979), Geology in the Siting of Nuclear Power Plants, Geological Society of America, Reviews in Engineering Geology, Volume IV, 1979.

Heaton, T. H., and S. H. Hartzell (1989), Estimation of strong ground motions for hypothetical earthquakes on the Cascadia subduction zone, Pacific Northwest, Pure Applied Geophysics. 129, 131-201.

Hoblitt, R. P., C.D. Miller, and W. E. Scott (1987), Volcanic Hazards with Regard to Siting Nuclear-Power Plants in the Pacific Northwest, U.S. Geological Survey, Open File Report 87-297.

Ho, F. P., et al. (1987), Hurricane Climatology for the Atlantic and Gulf Coast of the United States, NOAA Technical Report NWS 38, National Weather Service, April 1987.

Innen, S. M. and D. M. Hadley (1986), Prediction of strong ground motion in the Puget Sound region: The 1965 Seattle earthquake, Bull. Seism. Soc. Am. 76, 905-922. 
International Conference of Building Otficials (ICBO), Uniform Building Code, ICBO, Whittier, Califomia, 1991.

Joyner, W. B. and D. M. Boore (1988), Measurement, Characterization, and Prediction of Strong Ground Motion, in proc. Conf. on Earthquake Eng. and Soil Dynamics II, GT Div/ASCE, Park City, Utah, 27-30 June 1988; 43-102.

Langston, C. A. (1981), A study of Puget Sound strong ground motion, Bull. Seism. Soc. Am. 71, 883903.

Lawrence Livermore National Laboratory (1990), Assessment of Potential Volcanic Hazards for New Production Reactor Site at the Idaho National Engineering Laboratory, UCRL-ID-104722, Lawrence Livermore National Laboratory, Livermore, CA.

McCann, M. W. and A. C. Boissonnade (1988a), Preliminary Flood Hazard Estimates for Screening Department of Energy Sites, UCRL-21045, Lawrence Livermore National Laboratory, Livermore, CA.

McCann, M. W. and A. C. Boissonnade (1988b), Probabilistic Flood Hazard Assessment for the N Reactor, Hanford, Washington, UCRL-21069, Lawrence Livermore National Laboratory, Livermore, CA.

McCann, M. W. and A. C. Boissonnade (1991), Flood Hazard Evaluation for the Department of Energy New Production Reactor Site - Idaho National Engineering Laboratory, Prepared for Office of the New Production Reactor, United States Department of Energy, Prepared for Lawrence Livermore National Laboratory, Jack R. Bernjamin and Associates, Inc., July 1991.

McConnell, K. I., M. E. Blackford, and A.-K. Ibrahim (1992), Staff Technical Position on Investigations to Identity Fault Displacement Hazards at a Geologic Repository, U.S. Nuclear Regulatory Commission, Office of Nuclear Material Safety and Safeguards, NUREG-1451.

National Research Council (1988), Probabilistic Seismic Hazard Analysis, National Academy Press, Washington, D.C.

Seed, H.B. and I. M. Idriss (1982), Ground Motions and Soil Liquefaction during Earthquakes, Earthquake Engineering Research Institute, Oakland, California, Monograph Series, 134p. 
Seed, H. B., K. Tokimatsu, L. F. Harder, and R. M. Chung (1985), Influence of SPT Procedures in Soil Liquefaction Resistance Evaluation, Journal of the Geotechnical Engineering Division, ASCE, 111, GT12, 1425-1273.

Simiu, E., M. J. Changery, and J. J. Filliben (1979), Extreme Wind Speeds at 129 Stations in the Contiguous United States, Building Science Series Report 118, National Bureau of Standards, Washington, DC.

Southern Building Code Congress International (SBCCI), Standard Building Code, 1992 Amendment.

Tilling, R. I. (1989), Volcanic Hazards and their Mitigation: Progress and Problems, Reviews of Geophysics, 27:2, 237-269.

U. S. Nuclear Regulatory Commission (1992a), Identification and Characterization of Seismic Sources, Deterministic Source Earthquakes, and Ground Motions, Draft Regulatory Guide DG-1015, November 1992.

U. S. Nuclear Regulatory Commission (1992b), General Site Suitability Criteria for Nuclear Power Stations, Draft Regulatory Guide DG-4003 (Proposed Revision 2 to Regulatory Guide 4.7), November 1992.

U. S. Nuclear Regulatory Commission (1992c), Standard Review Plan 2.5.2, Vibratory Ground Motion, Proposed Revision 3, November 1992.

Wong, I. G., W. J. Silva, and I. P. Madin (1993), Strong ground shaking in the Portland, Oregon, metropolitan area: Evaluating the effects of local crustal and Cascadia subduction zone earthquakes and near-surface geology, Oregon Geology 55, 137-143.

Youngs, R. R., S. M. Day, and J. L. Stevens (1988), Near field ground motions on rock for large subduction earthquakes, in Proc. Conf. on Earthquake Eng. and Soil Dynamics II, GT Div/ASCE, Park City, Utah, 27-30 June 1988; 445-462. 
Review Activity:

$\begin{array}{lc}\text { DOE } & \text { Field Offices } \\ \text { DP } & \text { AL } \\ \text { EH } & \text { CH } \\ \text { EM } & \text { ID } \\ \text { NE } & \text { NV } \\ \text { NS } & \text { OR } \\ \text { RW } & \text { RL } \\ \text { ER } & \text { SF } \\ \text { AD } & \text { SR } \\ \text { FE } & \text { Fernald }\end{array}$

National Laboratories

BNL

LLNL

LANL

PNL

Sandia
Preparing Activity:

DOE-EH-64

Project Number:

FACR-0008

\footnotetext{
Area Offices

Amarillo Area Office

Kirtland Area Office

Princeton Area Office

Rocky Flats Area Office
} 


\begin{tabular}{|l|l}
\hline 1. Document Number & 2. Document Title \\
\hline
\end{tabular}

Name of Submitting Organization

4. Type of Organization (Mark one)
$\square$ Vendor
$\square$ User
$\square$ Manufacturer
$\square$ Other (Specity:
-)

. Problem Areas (Attach extra sheels as needed.)

a. Paragraph Number and Wording

b. Recommended Wording

c. Reason/Rationale for Recommendation 
INSTRUCTIONS: In a continuing effort to improve the U.S. Department of Energy (DOE) Technical Standards, this form provided for use in submitting comments and suggestions for improvements. All users of DOE Technical Standards invited to provide suggestions. This form may be detached. folded along the lines indicated, taped along the loose edge NOT STAPLE) mailed to the address indicated or faxed to (615) 574-0382.

1. The submitter of this form must complete blocks 1 through 8

2. The Lead Standardization Activity will forward this form to the Preparing Activity. The Preparing Activity will reply to the Submitter within 30 calendar days of receipt from the LSA.

NOTE: This form may not be used to request copies of documents, nor to request waivers, deviations, or clarification . specification requirements on current contractors. Comments submitted on this form do not constitute or imply authorizatic to waive any portion of the referenced document(s) or to amend contractual requirements.

\section{OMB Burden Disclosure Statement}

Public reporting burden for this collection of information is estimated to average 30 minutes per response, including the tir for reviewing instructions, searching existing data sources, gathering and maintaining the data needed, and completing as reviewing the collection of information. Send comments regarding this burden estimate or any other aspect of this collection information, including suggestions for reducing this burden, to Office of Information Resources Management Policy, Plar and Oversight Records Management Division. HR-422 - GTN. Paperwork Reduction Project (1910-0900), U.S. Department Energy, 1000 Independence Avenue. S.W. Washington. DC 20585; and to the Office of Management and Budget (OMI Paperwork Reduction Project (1910-0900). Washington. DC 20503.

U.S. Department of Energy Lead Standardization Activity c/o Performance Assurance Project Office

P.O. Box 2009, Bldg. 9201-3

Oak Ridge, Tennessee 37831-8065 

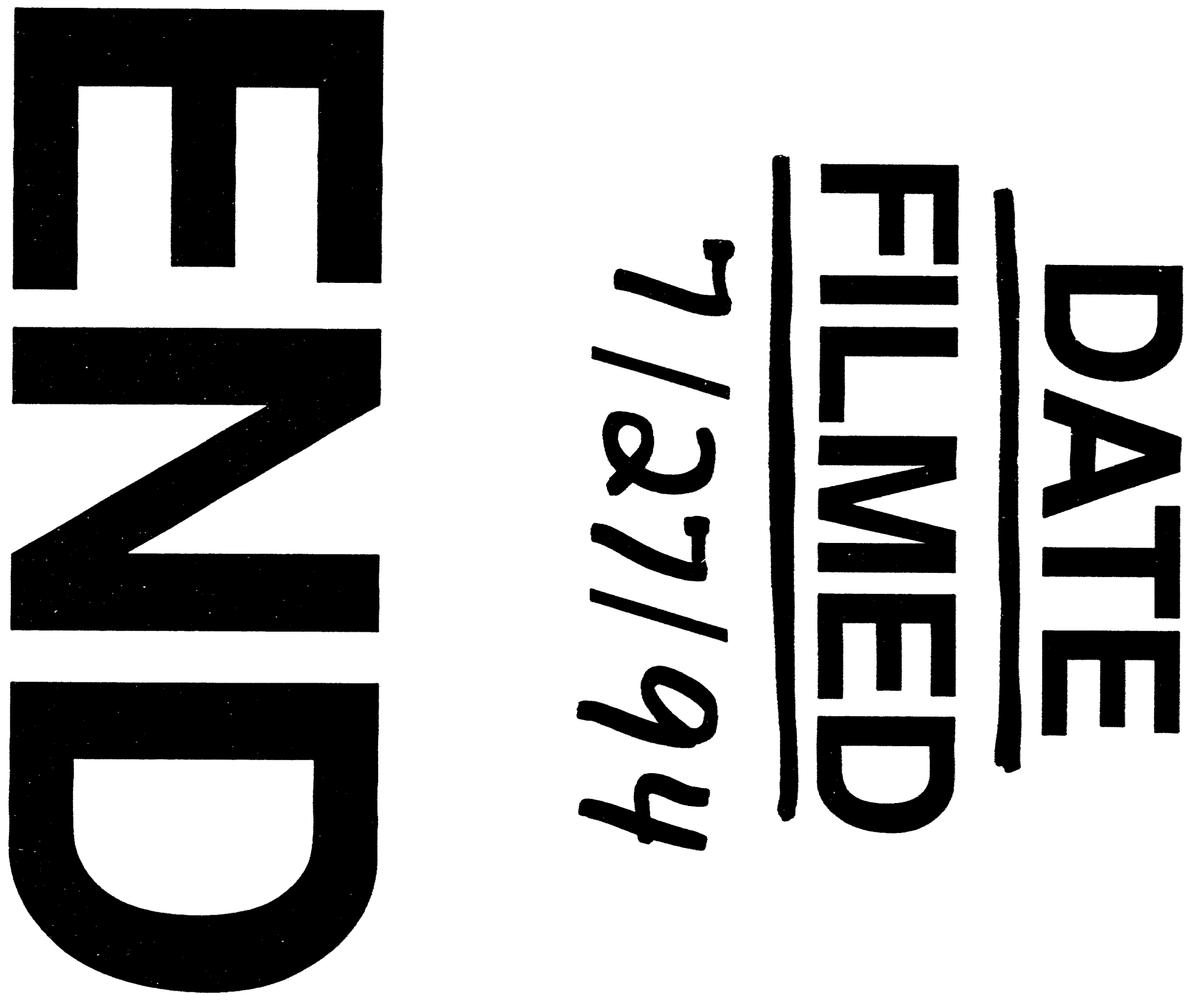
